\title{
LEVEL II SCOUR ANALYSIS FOR BRIDGE 18 (GROTTH00480018) on TOWN HIGHWAY 48, crossing the WELLS RIVER, GROTON, VERMONT
}

U.S. Geological Survey Open-File Report 97-626

Prepared in cooperation with

VERMONT AGENCY OF TRANSPORTATION and

FEDERAL HIGHWAY ADMINISTRATION 


\section{LEVEL II SCOUR ANALYSIS FOR BRIDGE 18 (GROTTH00480018) on TOWN HIGHWAY 48, crossing WELLS RIVER, GROTON, VERMONT \\ By LORA K. STRIKER AND LAURA MEDALIE}

U.S. Geological Survey

Open-File Report 97-626

Prepared in cooperation with

VERMONT AGENCY OF TRANSPORTATION

and

FEDERAL HIGHWAY ADMINISTRATION 


\title{
U.S. DEPARTMENT OF THE INTERIOR BRUCE BABBITT, Secretary
}

\author{
U.S. GEOLOGICAL SURVEY \\ Gordon P. Eaton, Director
}

For additional information write to:

District Chief

U.S. Geological Survey 361 Commerce Way

Pembroke, NH 03275-3718
Copies of this report may be purchased from:

U.S. Geological Survey

Branch of Information Services

Open-File Reports Unit

Box 25286

Denver, CO 80225-0286 


\section{CONTENTS}

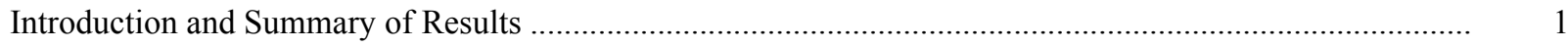

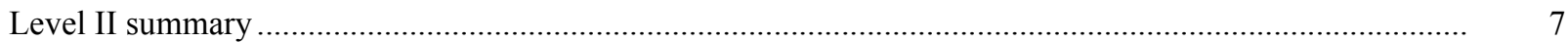

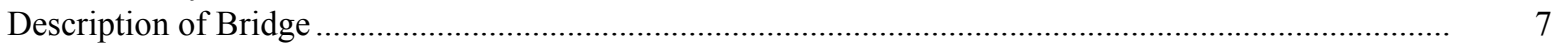

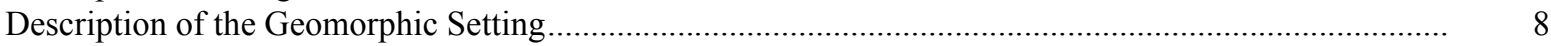

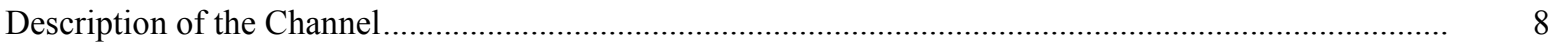

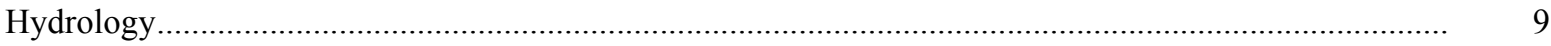

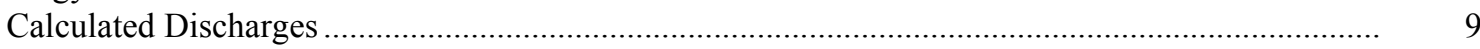

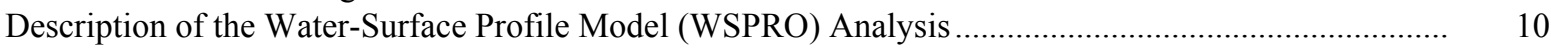

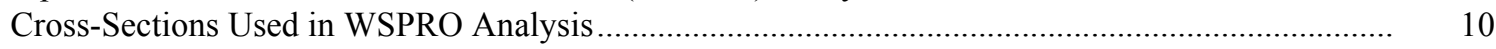

Data and Assumptions Used in WSPRO Model ...................................................................... 11

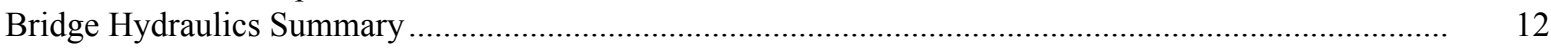

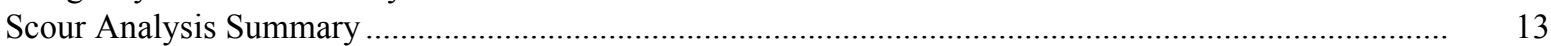

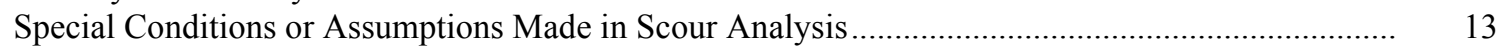

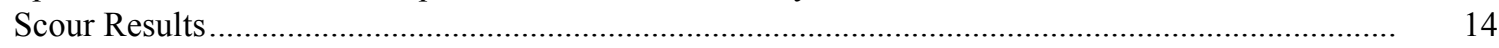

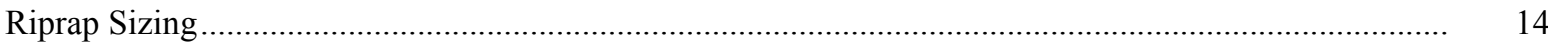

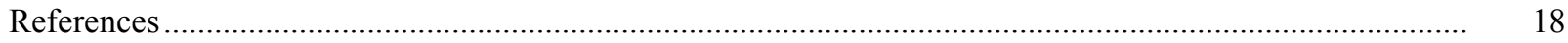

Appendixes:

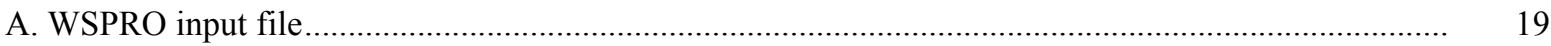

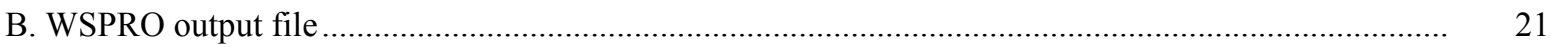

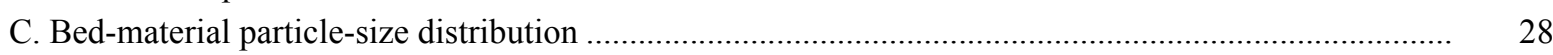

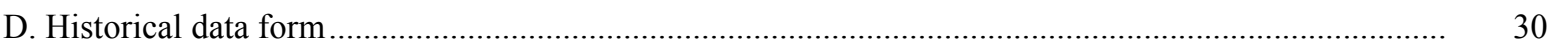

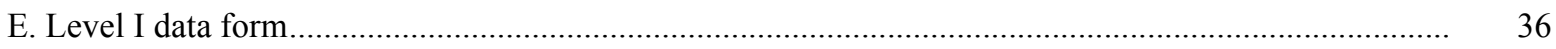

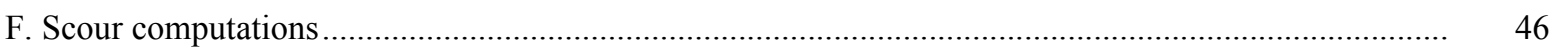

\section{FIGURES}

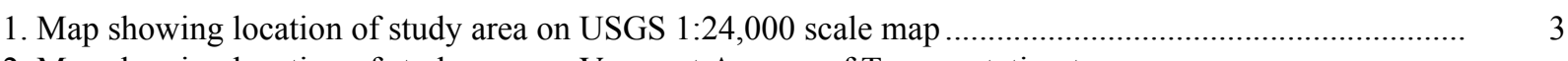

2. Map showing location of study area on Vermont Agency of Transportation town
highway map

3. Structure GROTTH00480018 viewed from upstream (August 28, 1995) ............................................ 5

4. Downstream channel viewed from structure GROTTH00480018 (August 28, 1995) ........................... 5

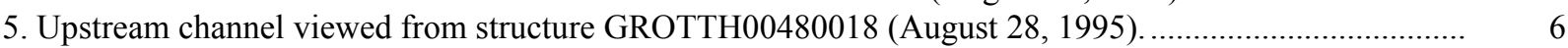

6. Structure GROTTH00480018 viewed from downstream (August 28, 1995)...................................... 6

7. Water-surface profiles for the 100- and 500-year discharges at structure

GROTTH00480018 on Town Highway 48, crossing Wells River,

Groton, Vermont.

8. Scour elevations for the 100- and 500-year discharges at structure

GROTTH00480018 on Town Highway 48, crossing Wells River,

Groton, Vermont.

\section{TABLES}

1. Remaining footing/pile depth at abutments for the 100-year discharge at structure

GROTTH00480018 on Town Highway 48, crossing Wells River,

Groton, Vermont .

2. Remaining footing/pile depth at abutments for the 500-year discharge at structure

GROTTH00480018 on Town Highway 48, crossing Wells River,

Groton, Vermont 


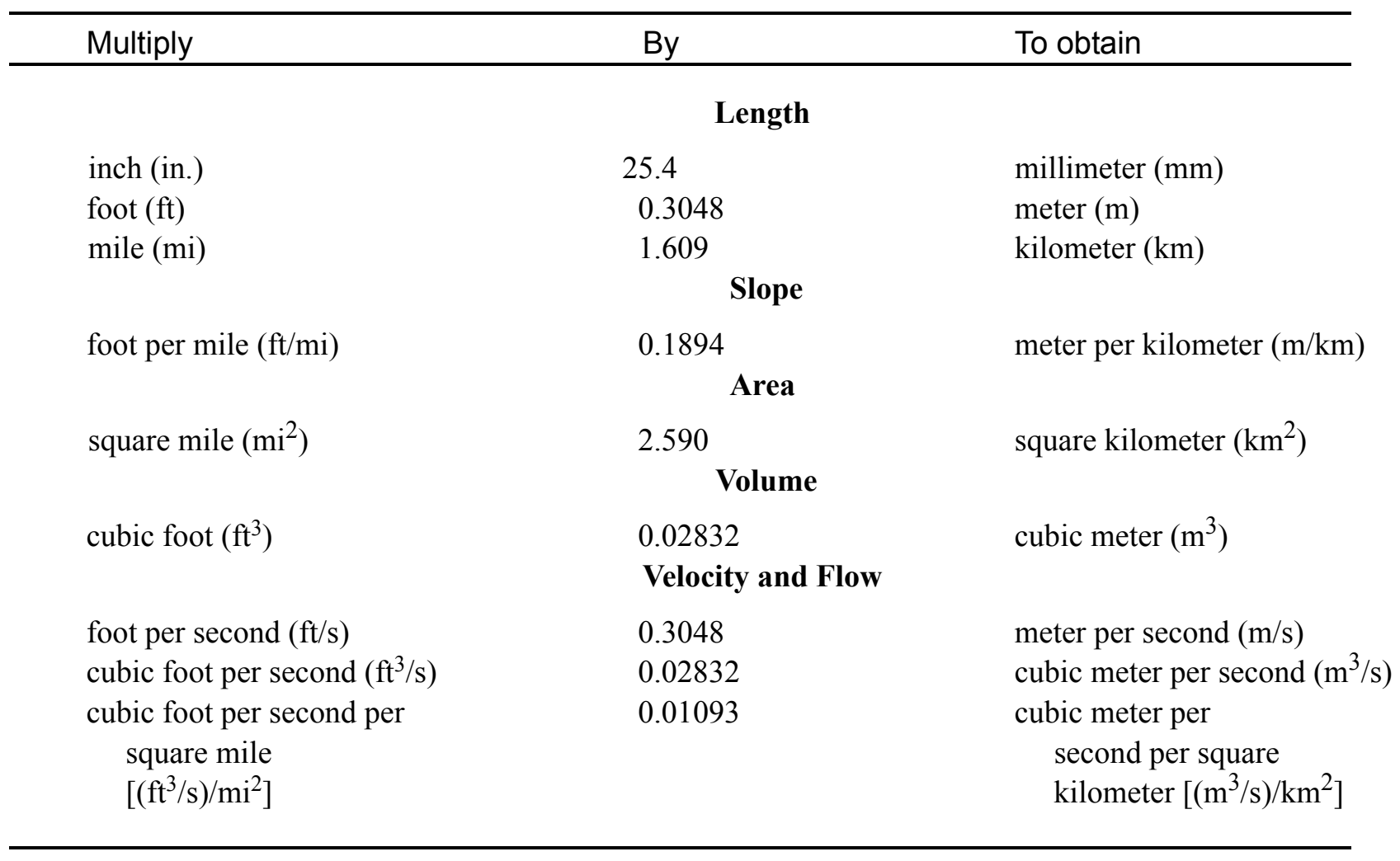

\section{OTHER ABBREVIATIONS}

$\begin{array}{lrlr}\mathrm{BF} & \text { bank full } & \text { LWW } & \text { left wingwall } \\ \mathrm{cfs} & \text { cubic feet per second } & \text { MC } & \text { main channel } \\ \mathrm{D}_{50} & \text { median diameter of bed material } & \text { RAB } & \text { right abutment } \\ \mathrm{DS} & \text { downstream } & \text { RABUT } & \text { face of right abutment } \\ \mathrm{elev} & \text { elevation } & \text { RB } & \text { right bank } \\ \mathrm{f} / \mathrm{p} & \text { flood plain } & \text { ROB } & \text { right overbank } \\ \mathrm{ft}^{2} & \text { square feet } & \text { RWW } & \text { right wingwall } \\ \mathrm{ft} / \mathrm{ft} & \text { feet per foot } & \text { TH } & \text { town highway } \\ \mathrm{JCT} & \text { junction } & \text { UB } & \text { under bridge } \\ \mathrm{LAB} & \text { left abutment } & \text { US } & \text { upstream } \\ \mathrm{LABUT} & \text { face of left abutment } & \text { USGS } & \text { United States Geological Survey } \\ \mathrm{LB} & \text { left bank } & \text { VTAOT Vermont Agency of Transportation } \\ \mathrm{LOB} & \text { left overbank } & \text { WSPRO } & \text { water-surface profile model }\end{array}$

In this report, the words "right" and "left" refer to directions that would be reported by an observer facing downstream. Sea level: In this report, "sea level" refers to the National Geodetic Vertical Datum of 1929-- a geodetic datum derived from a general adjustment of the first-order level nets of the United States and Canada, formerly called Sea Level Datum of 1929.

In the appendices, the above abbreviations may be combined. For example, USLB would represent upstream left bank. 


\title{
LEVEL II SCOUR ANALYSIS FOR BRIDGE 18 (GROTTH00480018) ON TOWN HIGHWAY 48, CROSSING WELLS RIVER, GROTON, VERMONT
}

\author{
By Lora K. Striker and Laura Medalie
}

\section{INTRODUCTION AND SUMMARY OF RESULTS}

This report provides the results of a detailed Level II analysis of scour potential at structure GROTTH00480018 on Town Highway 48 crossing the Wells River, Groton, Vermont (figures 1-8). A Level II study is a basic engineering analysis of the site, including a quantitative analysis of stream stability and scour (U.S. Department of Transportation, 1993). Results of a Level I scour investigation also are included in Appendix E of this report. A Level I investigation provides a qualitative geomorphic characterization of the study site. Information on the bridge, gleaned from Vermont Agency of Transportation (VTAOT) files, was compiled prior to conducting Level I and Level II analyses and is found in Appendix D.

The site is in the New England Upland section of the New England physiographic province in eastern Vermont. The $53.6-\mathrm{mi}^{2}$ drainage area is in a predominantly rural and forested basin. In the vicinity of the study site, the surface cover is pasture on the right bank upstream and the left bank downstream while the surface cover is shrub and brushland along the left bank upstream and the right bank downstream. The immediate banks are vegetated with brush and scattered trees.

In the study area, the Wells River has an incised, straight channel with a slope of approximately $0.003 \mathrm{ft} / \mathrm{ft}$, an average channel top width of $69 \mathrm{ft}$ and an average bank height of $7 \mathrm{ft}$. The channel bed material ranges from sand to cobble with a median grain size $\left(\mathrm{D}_{50}\right)$ of $66.7 \mathrm{~mm}(0.219 \mathrm{ft})$. The geomorphic assessment at the time of the Level I and Level II site visit on August 28, 1995, indicated that the reach was stable.

The Town Highway 48 crossing of the Wells River is a 38-ft-long, one-lane bridge consisting of one 36-foot steel-beam span (Vermont Agency of Transportation, written communication, March 24, 1995). The opening length of the structure parallel to the bridge face is $33.7 \mathrm{ft}$. The bridge is supported by vertical, concrete abutments with wingwalls. The channel is skewed approximately 0 degrees to the opening and the opening-skew-toroadway is also 0 degrees. 
Local scour $3.25 \mathrm{ft}$ deeper than the mean thalweg depth was observed underneath the bridge along the left and right abutments during the Level I assessment. In addition, a scour hole extends from $90 \mathrm{ft}$ US to $50 \mathrm{ft}$ DS for a total length of $115 \mathrm{ft}$ with an average scour depth of $2.0 \mathrm{ft}$. The only scour protection measure at the site was type- 2 stone fill (less than 36 inches diameter) along the left bank upstream, along the entire base length of the downstream right wingwall, and along the left and right banks downstream; and type-1 stone fill (less than 12 inches diameter) along the entire base length of the upstream left wingwall. Additional details describing conditions at the site are included in the Level II Summary and Appendices D and E.

Scour depths and recommended rock rip-rap sizes were computed using the general guidelines described in Hydraulic Engineering Circular 18 (Richardson and others, 1995) for the 100- and 500-year discharges. In addition, the incipient roadway-overtopping discharge is determined and analyzed as another potential worst-case scour scenario. Total scour at a highway crossing is comprised of three components: 1) long-term streambed degradation; 2) contraction scour (due to accelerated flow caused by a reduction in flow area at a bridge) and; 3 ) local scour (caused by accelerated flow around piers and abutments). Total scour is the sum of the three components. Equations are available to compute depths for contraction and local scour and a summary of the results of these computations follows.

Contraction scour for all modelled flows was $0.0 \mathrm{ft}$. Abutment scour ranged from 2.0 to 2.3 $\mathrm{ft}$ at the left abutment and 8.8 to $14.6 \mathrm{ft}$ at the right abutment. The worst-case abutment scour occurred at the 500-year discharge at the right abutment. Additional information on scour depths and depths to armoring are included in the section titled "Scour Results". Scoured-streambed elevations, based on the calculated scour depths, are presented in tables 1 and 2. A cross-section of the scour computed at the bridge is presented in figure 8 . Scour depths were calculated assuming an infinite depth of erosive material and a homogeneous particle-size distribution.

It is generally accepted that the Froehlich equation (abutment scour) gives "excessively conservative estimates of scour depths" (Richardson and others, 1995, p. 47). Usually, computed scour depths are evaluated in combination with other information including (but not limited to) historical performance during flood events, the geomorphic stability assessment, existing scour protection measures, and the results of the hydraulic analyses. Therefore, scour depths adopted by VTAOT may differ from the computed values documented herein. 


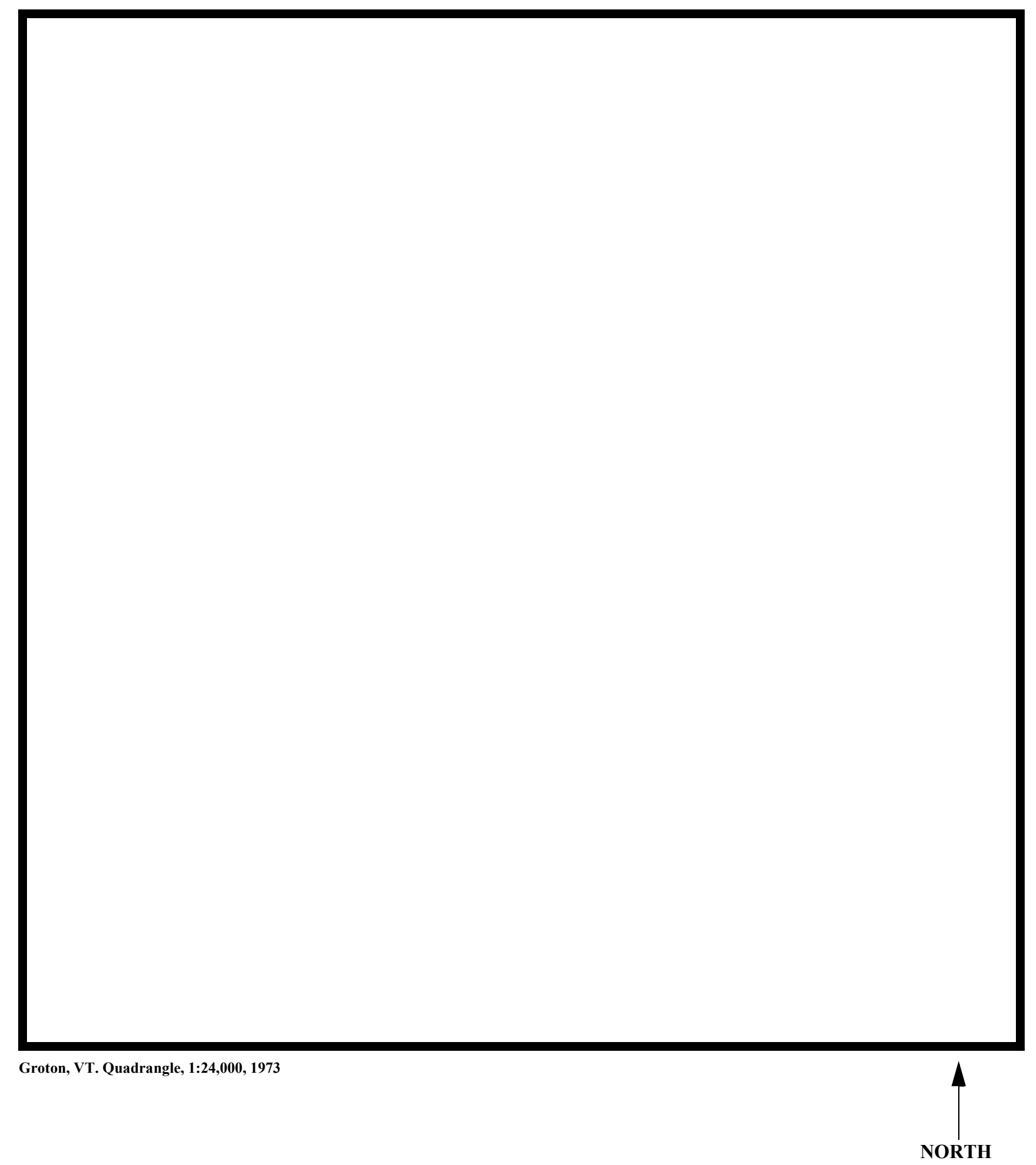

Figure 1. Location of study area on USGS 1:24,000 scale map. 
Figure 2. Location of study area on Vermont Agency of Transportation town highway map. 

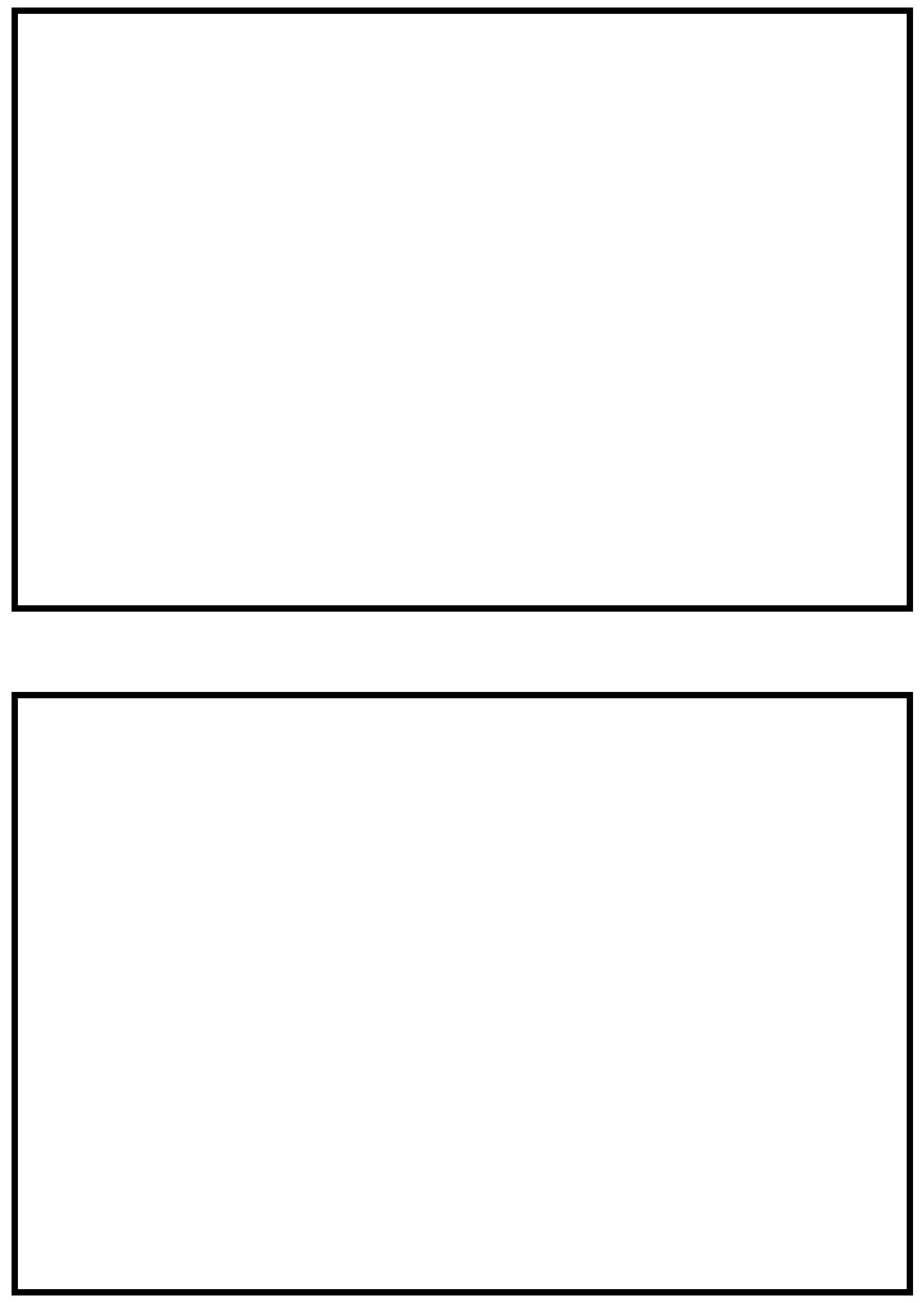

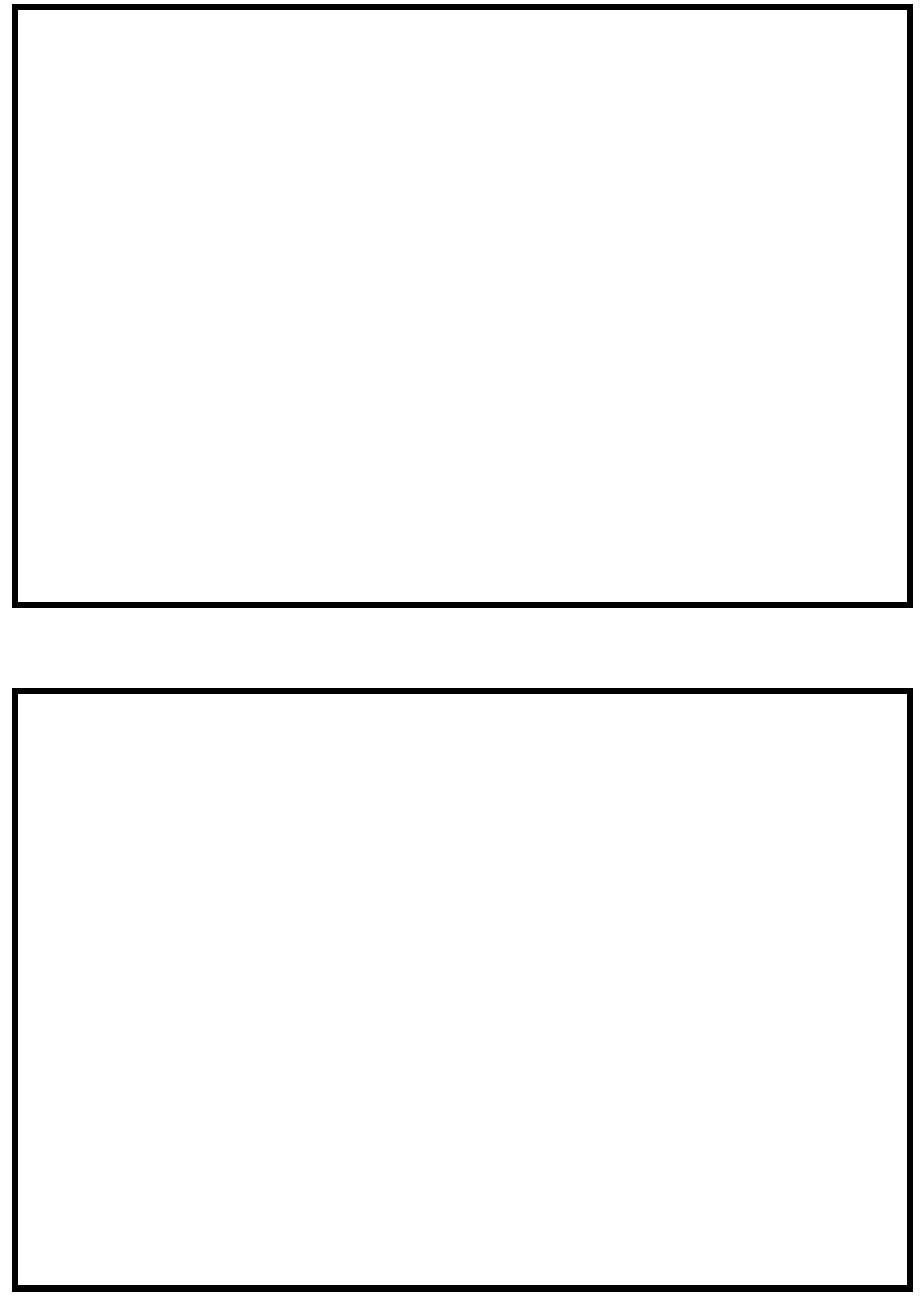


\section{LEVEL II SUMMARY}

\begin{tabular}{llllll} 
Structure Number & GROTTH00480018 & Stream & \multicolumn{2}{c}{ Wells River } & \\
& Road & TH 48 & District & R
\end{tabular}

\section{Description of Bridge}

Bridge length $\frac{38}{3} \boldsymbol{f t}$ Bridge width $\frac{13.1}{f t}$ Max span length $\frac{36}{f t}$ Alignment of bridge to road (on curve or straight)

Abutment type Vertical, concrete

Stone fill on abutment?

$$
\text { No }
$$

\section{Embankment type} Straight

nacamintin.. af atan a fill Type-1, along the entire base length of the upstream left wingwall, and
Sloping

$08 / 28 / 95$

type-2 along the entire base length of the downstream right wingwall.

Abutments and wingwalls are concrete. The upstream

right wingwall is concrete for the first 10 feet and then piled granite blocks for another 10 feet. The

LABUT and RABUT are undermined slightly.

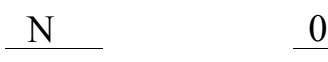

Is bridge skewed to flood flow according to N ' survey? Angle

Debris accumulation on bridge at time of Level I or Level II site visit:

\begin{tabular}{|c|c|c|c|}
\hline & $\begin{array}{c}\text { Date of insnortion } \\
08 / 28 / 95 \\
\end{array}$ & $\begin{array}{l}\text { Percent of ahmunal } \\
\text { blocked inortzontatly }\end{array}$ & $\begin{array}{l}\text { Percent of } 0 \\
\text { blocked verticatty }\end{array}$ \\
\hline & $08 / 28 / 95$ & 0 & 0 \\
\hline
\end{tabular}

Level I

Low. There are some trees leaning into the channel upstream.

Level II

Potential for debris

None, $08 / 28 / 95$

Doscriho anv, fonturos noar ar at tho hridoo that mav, affort flow, (includo ahsorvation dato) 


\section{Description of the Geomorphic Setting}

General topography The channel is located within a moderate relief valley with narrow

floodplains.

Geomorphic conditions at bridge site: downstream (DS), upstream (US)

Date of inspection $\quad 08 / 28 / 95$

DS left: $\quad$ Steep channel bank to a narrow floodplain

DS right: $\quad$ Steep channel bank to a narrow floodplain

US left: $\quad$ Steep channel bank with natural levee to irregular overbank

US right: $\quad$ Steep channel bank with natural levee to a narrow flood plain

\section{Description of the Channel}

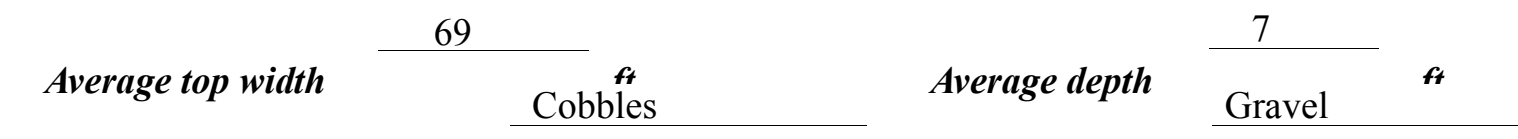

Predominant bed material

Bank material Straight and stable

with alluvial channel boundaries and a narrow flood plain.

$08 / 28 / 95$

Vegetative co ${ }^{1}$ Brush on the immediate banks with a pasture overbank

DS left: $\quad$ Brush

DS right: $\quad$ Brush

US left: $\quad$ Brush with a few trees with a pasture overbank

US right:

$\mathrm{Y}$

Do banks appear stable? -

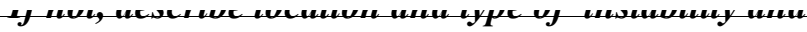

date of observatton.

None, 08/28/95.

Describe any obstructions in channel and date of observation. 


\section{Hydrology}

Drainage area $\stackrel{53.6}{\mathrm{mi}^{2}}$

Percentage of drainage area in physiographic provinces: (approximate)

Physiographic province/section New England/New England Upland
Percent of drainage area 100

Is drainage area considered rural or urban?

Rural None.

urbanization:

Is there a USGS gage on the stream of interest?

Yes

Wells River at Wells River, VT

USGS gage description

01139000

USGS gage number

Gage drainage area $\quad \mathrm{mi}^{2}$

Describe any significant Yes

Is there a lake/p There are discharge records available from August $\ddot{1940}$ to current year.

The flow of Wells River is partly regulated by Groton and Ricker Ponds. Ricker Pond is located

2.5 miles upstream of this site.

\begin{tabular}{llll}
3,700 & \multicolumn{2}{c}{ Calculated Discharges } & 5,100 \\
& $f t^{3} / \mathrm{s}$ & $\mathbf{Q 5 0 0}$ & $f t^{3} / \mathrm{s}$
\end{tabular}

The 100- and 500-year discharges were taken

directly from FEMA discharge estimates below the confluence of the North Branch of the Wells River. A drainage area estimate from FEMA for this location, located 0.3 miles upstream of the bridge site, is not available. Therefore, the discharges were used directly since there is no significant contribution to the flow within this distance. The discharges used are within range of several empirical methods. (Benson, 1962; Johnson and Tasker, 1974; FEMA, 1991; FHWA, 1983; Potter, 1957a\&b; Talbot, 1887) 


\section{Description of the Water-Surface Profile Model (WSPRO) Analysis}

Datum for WSPRO analysis (USGS survey, sea level, VTAOT plans)

USGS survey

Datum tie between USGS survey and VTAOT plans

None

Description of reference marks used to determine USGS datum. $\quad$ RM1 is a chiseled X on

top of the downstream end of the right abutment (elev. $499.42 \mathrm{ft}$, arbitrary survey datum). RM2

is a chiseled square on top of the downstream end of the left abutment (elev. $498.62 \mathrm{ft}$, arbitrary

survey datum). RM2 is RM30 from FEMA (elev. $805.71 \mathrm{ft}, \mathrm{NGVD}$ of 1929).

\section{Cross-Sections Used in WSPRO Analysis}

\begin{tabular}{cccl}
\hline${ }^{1}$ Cross-section & $\begin{array}{c}\text { Section } \\
\text { Reference } \\
\text { Distance } \\
(\text { SRD) } \text { in feet }\end{array}$ & $\begin{array}{c}{ }^{2} \text { Cross-section } \\
\text { development }\end{array}$ & \multicolumn{1}{c}{ Comments } \\
\hline EXITX & -41 & 1 & Exit section \\
FULLV & 0 & 2 & $\begin{array}{l}\text { Downstream Full-valley } \\
\text { section (Templated from } \\
\text { EXITX) }\end{array}$ \\
BRIDG & 0 & 1 & $\begin{array}{l}\text { Bridge section } \\
\text { Road Grade section } \\
\text { RDWAY }\end{array}$ \\
APPRO & 8 & 1 & $\begin{array}{l}\text { Approach section as sur- } \\
\text { veyed }\end{array}$ \\
\hline
\end{tabular}

${ }^{1}$ For location of cross-sections see plan-view sketch included with Level I field form, Appendix E. For more detail on how cross-sections were developed see WSPRO input file. 


\section{Data and Assumptions Used in WSPRO Model}

Hydraulic analyses of the reach were done by use of the Federal Highway Administration's WSPRO step-backwater computer program (Shearman and others, 1986, and Shearman, 1990). The analyses reported herein reflect conditions existing at the site at the time of the study. Furthermore, in the development of the model it was necessary to assume no accumulation of debris or ice at the site. Results of the hydraulic model are presented in the Bridge Hydraulic Summary, Appendix B, and figure 7.

Channel roughness factors (Manning's “ $n$ ”) used in the hydraulic model were estimated using field inspections at each cross section following the general guidelines described by Arcement and Schneider (1989). Final adjustments to the values were made during the modelling of the reach. Channel " $n$ " values for the reach ranged from 0.040 to 0.055 , and overbank " $n$ " values ranged from 0.040 to 0.070 .

Normal depth at the exit section (EXITX) was assumed as the starting water surface. This depth was computed by use of the slope-conveyance method outlined in the user's manual for WSPRO (Shearman, 1990). The slope used was $0.0028 \mathrm{ft} / \mathrm{ft}$, which was estimated from the 500-year water surface elevation downstream of the bridge site (Federal Emergency Management Agency, 1991).

The surveyed approach section (APPRO) was taken one bridge length upstream of the upstream face as recommended by Shearman and others (1986). This location also provides a consistent method for determining scour variables. 


\section{Bridge Hydraulics Summary}

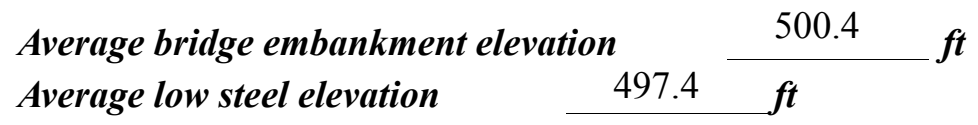

$$
\text { 100-year discharge } \quad 3,700 \quad \mathrm{ft}^{3} / \mathrm{s}
$$

Water-surface elevation in bridge opening $\quad 497.5 \quad f t$

Road overtopping? ___ Y Discharge over road _ـ 1,100 $\mathrm{ft}^{3} / \mathrm{s}$

\begin{tabular}{lll} 
Area of flow in bridge opening & $343 \quad \mathrm{ft}^{2}$ \\
\cline { 2 - 3 } Average velocity in bridge opening & 7.6 & $\mathrm{ft} / \mathrm{s}$
\end{tabular}

$\begin{array}{llll}\text { Maximum WSPRO tube velocity at bridge } & 9.0 \mathrm{ft} / \mathrm{s}\end{array}$

Water-surface elevation at Approach section with bridge 498.6

Water-surface elevation at Approach section without bridge $\quad \overline{496.9}$

Amount of backwater caused by bridge

$1.7 \quad i$

500-year discharge $\quad 5,100 \quad \mathrm{ft}^{3} / \mathrm{s}$

Water-surface elevation in bridge opening

$497.5 \mathrm{ft}$

Road overtopping? ___ Y Discharge over road _ $2200, \ldots$

Area of flow in bridge opening $\quad 343 \quad \mathrm{ft}^{2}$

Average velocity in bridge opening $8.4 \mathrm{ft} / \mathrm{s}$

Maximum WSPRO tube velocity at bridge 10.0 /s

Water-surface elevation at Approach section with bridge 499.3

Water-surface elevation at Approach section without bridge $\quad 497.6$

Amount of backwater caused by bridge $\quad 1.7$.t

Incipient overtopping discharge $\quad 2,630 \quad \mathrm{ft}^{3} / \mathrm{s}$

Water-surface elevation in bridge opening $495.8 \quad t$

Area of flow in bridge opening $\quad 288 \quad \mathrm{ft}^{2}$

Average velocity in bridge opening $\quad 9.1 \quad \mathrm{ft} / \mathrm{s}$

Maximum WSPRO tube velocity at bridge $\quad 11.5 \mathrm{ft} / \mathrm{s}$

Water-surface elevation at Approach section with bridge

Water-surface elevation at Approach section without bridge

496.9

Amount of backwater caused by bridge $\quad \begin{array}{ll}0.6 \\ \text { it }\end{array}$

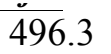




\section{Scour Analysis Summary}

\section{Special Conditions or Assumptions Made in Scour Analysis}

Scour depths were computed using the general guidelines described in Hydraulic Engineering Circular 18 (Richardson and others, 1995). Scour depths were calculated assuming an infinite depth of erosive material and a homogeneous particle-size distribution. The results of the scour analysis are presented in tables 1 and 2 and a graph of the scour depths is presented in figure 8 .

Contraction scour for the incipient roadway-overtopping discharge was computed by use of the Laursen clear-water contraction scour equation (Richardson and others, 1995, p. 32 , equation 20). At this site, the 100-year discharge resulted in unsubmerged orifice flow while the 500-year discharge resulted in submerged orifice flow. Contraction scour at bridges with orifice flow is best estimated by use of the Chang pressure-flow scour equation (oral communication, J. Sterling Jones, October 4, 1996). Thus, contraction scour for these discharges was computed by use of the Chang equation (Richardson and others, 1995, p. 145-146). The computed streambed armoring depths suggest that armoring will not limit the depth of contraction scour.

For comparison, contraction scour for the discharges resulting in orifice flow was also computed by use of the Laursen clear-water contraction scour equation and the Umbrell pressure-flow equation (Richardson and others, 1995, p. 144) and presented in Appendix F. Furthermore, for the 100-year discharge which resulted in unsubmerged orifice flow, contraction scour was computed by substituting estimates for the depth of flow at the downstream bridge face in the contraction scour equations. Results with respect to these substitutions are provided in Appendix F.

Scour at the abutments was computed by use of the HIRE equation (Richardson and others, 1995, p. 49, equation 29) because the HIRE equation is recommended when the length to depth ratio of the embankment blocking flow exceeds 25. Variables for the Hire equation include the Froude number of the flow approaching the embankments, the length of the embankment blocking flow, and the depth of flow approaching the embankment less any roadway overtopping. 


\section{Scour Results}

\section{0-yr discharge 500-yr discharge}

Contraction scour:

(Scour depths in feet)

Main channel

Live-bed scour

Clear-water scour

Depth to armoring

Left overbank

Right overbank

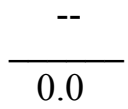

$0.4^{-}$
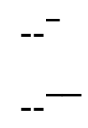
overtopping discharge

Local scour:

Abutment scour

Left abutment

2.3

2.0

2.2

$13.1-$

$14.6-$

8.8-

Right abutment

Pier scour

Pier 1

Pier 2

Pier 3

\section{Abutments:}

Left abutment

Right abutment

Piers:

Pier 1

Pier 2

\section{Riprap Sizing}

Incipient overtopping 100-yr discharge 500-yrdischarge discharge

1.2

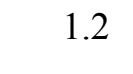

$--$
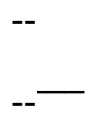
( $D_{50}$ in feet)

$1.4 \quad 1.6$

$1.4 \quad 1.6$
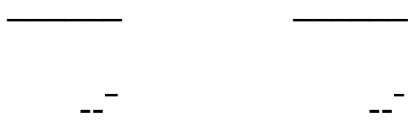

$-$

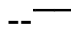




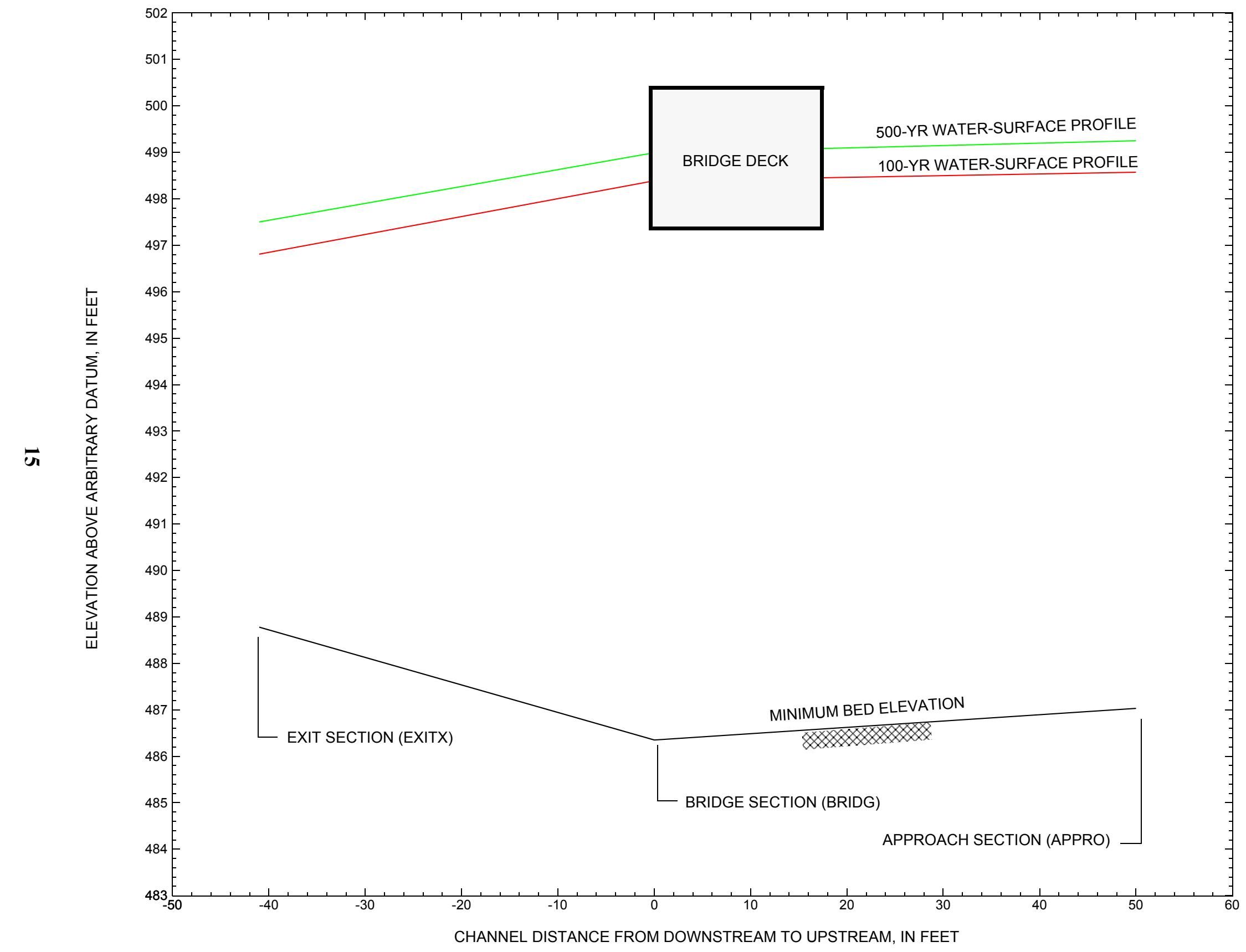

Figure 7. Water-surface profiles for the 100- and 500-year discharges at structure GROTTH00480018 on Town Highway 48, crossing Wells River, Groton, Vermont. 


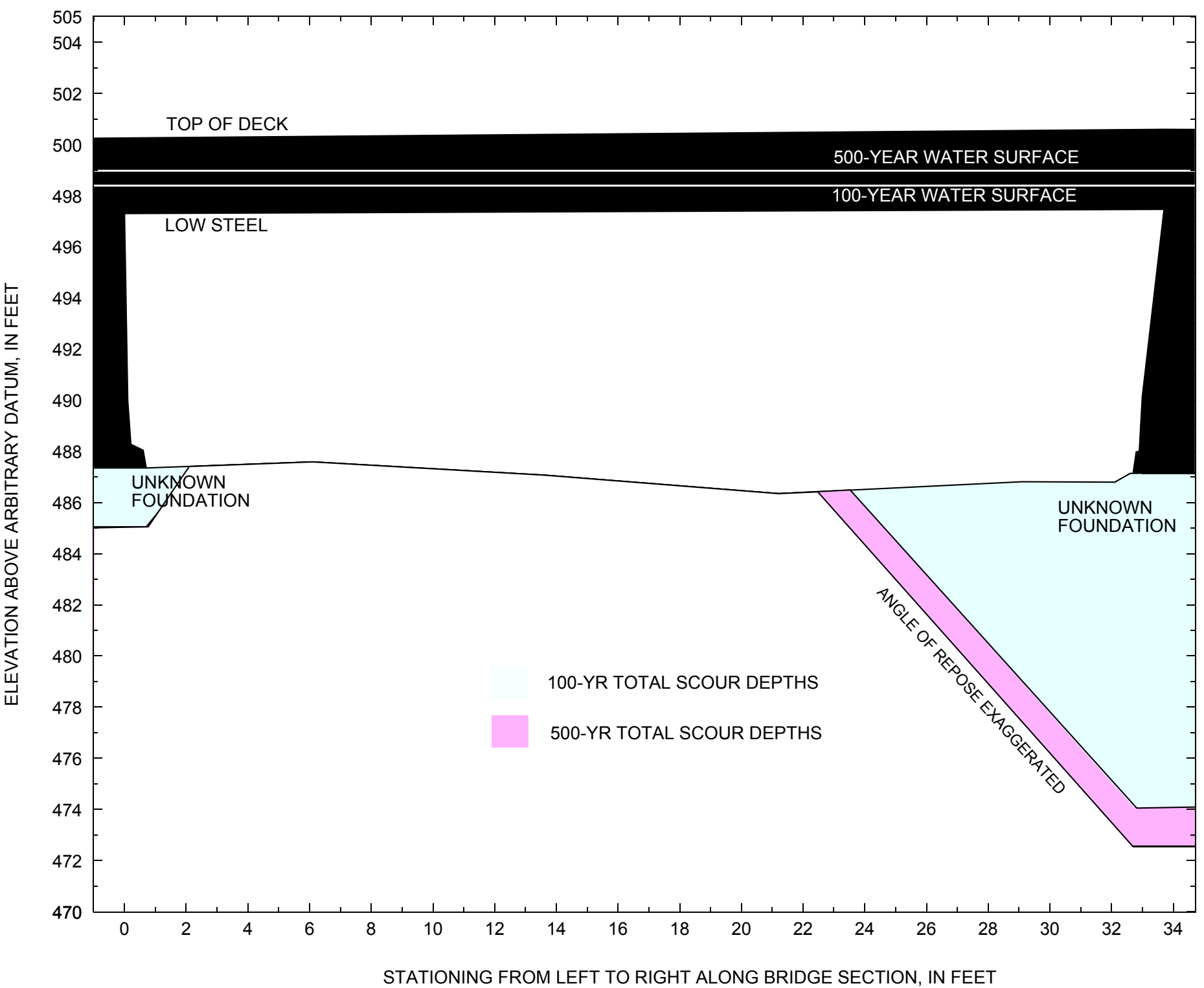

Figure 8. Scour elevations for the 100-year and 500-year discharges at structure GROTTH00480018 on Town Highway 48, crossing Wells River, Groton, Vermont. 


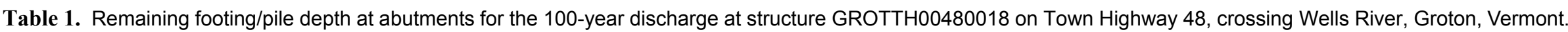
[VTAOT, Vermont Agency of Transportation; --,no data]

\begin{tabular}{|c|c|c|c|c|c|c|c|c|c|c|c|}
\hline Description & Station $^{1}$ & $\begin{array}{l}\text { VTAOT } \\
\text { minimum } \\
\text { low-chord } \\
\text { elevation } \\
\text { (feet) }\end{array}$ & $\begin{array}{l}\text { Surveyed } \\
\text { minimum } \\
\text { low-chord } \\
\text { elevation } \\
\text { (feet) }\end{array}$ & $\begin{array}{c}\text { Bottom of } \\
\text { footing/pile } \\
\text { elevation }{ }^{2} \\
\text { (feet) }\end{array}$ & $\begin{array}{c}\text { Channel } \\
\text { elevation at } \\
\text { abutment/ } \\
\text { pier }^{2} \\
\text { (feet) }\end{array}$ & $\begin{array}{l}\text { Contraction } \\
\text { scour depth } \\
\text { (feet) }\end{array}$ & $\begin{array}{l}\text { Abutment } \\
\text { scour } \\
\text { depth } \\
\text { (feet) }\end{array}$ & $\begin{array}{l}\text { Pier } \\
\text { scour } \\
\text { depth } \\
\text { (feet) }\end{array}$ & $\begin{array}{l}\text { Depth of } \\
\text { total scour } \\
\text { (feet) }\end{array}$ & $\begin{array}{c}\text { Elevation of } \\
\text { scour }^{2} \\
\text { (feet) }\end{array}$ & $\begin{array}{c}\text { Remaining } \\
\text { footing/pile } \\
\text { depth } \\
\text { (feet) }\end{array}$ \\
\hline \multicolumn{12}{|c|}{100 -yr. discharge is 3,700 cubic-feet per second } \\
\hline Left abutment & 0.0 & -- & 497.3 & -- & 487.3 & 0.0 & 2.3 & -- & 2.3 & 485.0 & -- \\
\hline Right abutment & 33.7 & -- & 497.5 & -- & 487.2 & 0.0 & 13.1 & -- & 13.1 & 474.1 & -- \\
\hline
\end{tabular}

1.Measured along the face of the most constricting side of the bridge.

2.Arbitrary datum for this study.

Table 2. Remaining footing/pile depth at abutments for the 500-year discharge at structure GROTTH00480018 on Town Highway 48, crossing Wells River, Groton, Vermont. [VTAOT, Vermont Agency of Transportation; --, no data]

\begin{tabular}{|c|c|c|c|c|c|c|c|c|c|c|c|}
\hline Description & Station $^{1}$ & $\begin{array}{l}\text { VTAOT } \\
\text { minimum } \\
\text { low-chord } \\
\text { elevation } \\
\text { (feet) }\end{array}$ & $\begin{array}{l}\text { Surveyed } \\
\text { minimum } \\
\text { low-chord } \\
\text { elevation } \\
\text { (feet) }\end{array}$ & $\begin{array}{c}\text { Bottom of } \\
\text { footing/pile } \\
\text { elevation }{ }^{2} \\
\text { (feet) }\end{array}$ & $\begin{array}{c}\text { Channel } \\
\text { elevation at } \\
\text { abutment/ } \\
\text { pier }^{2} \\
\text { (feet) }\end{array}$ & $\begin{array}{c}\text { Contraction } \\
\text { scour depth } \\
\text { (feet) }\end{array}$ & $\begin{array}{l}\text { Abutment } \\
\text { scour } \\
\text { depth } \\
\text { (feet) }\end{array}$ & $\begin{array}{l}\text { Pier } \\
\text { scour } \\
\text { depth } \\
\text { (feet) }\end{array}$ & $\begin{array}{l}\text { Depth of } \\
\text { total scour } \\
\text { (feet) }\end{array}$ & $\begin{array}{c}\text { Elevation of } \\
\text { scour }^{2} \\
\text { (feet) }\end{array}$ & $\begin{array}{c}\text { Remaining } \\
\text { footing/pile } \\
\text { depth } \\
\text { (feet) }\end{array}$ \\
\hline \multicolumn{12}{|c|}{500 -yr. discharge is 5,100 cubic-feet per second } \\
\hline Left abutment & 0.0 & -- & 497.3 & -- & 487.3 & 0.0 & 2.0 & -- & 2.0 & 485.3 & -- \\
\hline Right abutment & 33.7 & -- & 497.5 & -- & 487.2 & 0.0 & 14.6 & -- & 14.6 & 472.6 & -- \\
\hline
\end{tabular}

1.Measured along the face of the most constricting side of the bridge.

2.Arbitrary datum for this study. 


\section{SELECTED REFERENCES}

Arcement, G.J., Jr., and Schneider, V.R., 1989, Guide for selecting Manning's roughness coefficients for natural channels and flood plains:

U.S. Geological Survey Water-Supply Paper 2339, 38 p.

Barnes, H.H., Jr., 1967, Roughness characteristics of natural channels: U.S. Geological Survey Water-Supply Paper 1849,213 p.

Benson, M. A., 1962, Factors Influencing the Occurrence of Floods in a Humid Region of Diverse Terrain: U.S. Geological Survey WaterSupply Paper 1580-B, 64 p.

Brown, S.A. and Clyde, E.S., 1989, Design of riprap revetment: Federal Highway Administration Hydraulic Engineering Circular No. 11, Publication FHWA-IP-89-016, 156 p.

Federal Highway Administration, 1983, Runoff estimates for small watersheds and development of sound design: Federal Highway Administration Report FHWA-RD-77-158.

Federal Highway Administration, 1993, Stream Stability and Scour at Highway Bridges: Participant Workbook: Federal Highway Administration Report FHWA-HI-91-011.

Federal Emergency Management Agency, 1991, Flood Insurance Study, Town of Groton, Caledonia County, Vermont: Washington, D.C., September, 1991.

Froehlich, D.C., 1989, Local scour at bridge abutments in Ports, M.A., ed., Hydraulic Engineering--Proceedings of the 1989 National Conference on Hydraulic Engineering: New York, American Society of Civil Engineers, p. 13-18.

Hayes, D.C.,1993, Site selection and collection of bridge-scour data in Delaware, Maryland, and Virginia: U.S. Geological Survey WaterResources Investigation Report 93-4017, 23 p.

Interagency Advisory Committee on Water Data, 1982, Guidelines for determining flood flow frequency: U.S. Geological Survey, Bulletin 17B of the Hydrology Subcommittee, 190 p.

Johnson, C.G. and Tasker, G.D.,1974, Progress report on flood magnitude and frequency of Vermont streams: U.S. Geological Survey OpenFile Report 74-130, 37 p.

Lagasse, P.F., Schall, J.D., Johnson, F., Richardson, E.V., Chang, F., 1995, Stream Stability at Highway Structures: Federal Highway Administration Hydraulic Engineering Circular No. 20, Publication FHWA-IP-90-014, 144 p.

Laursen, E.M., 1960, Scour at bridge crossings: Journal of the Hydraulics Division, American Society of Civil Engineers, v. 86, no. HY2, p. 39-53.

Potter, W. D., 1957a, Peak rates of runoff in the Adirondack, White Mountains, and Maine woods area, Bureau of Public Roads

Potter, W. D., 1957b, Peak rates of runoff in the New England Hill and Lowland area, Bureau of Public Roads

Richardson, E.V. and Davis, S.R., 1995, Evaluating scour at bridges: Federal Highway Administration Hydraulic Engineering Circular No. 18, Publication FHWA-IP-90-017, 204 p.

Richardson, E.V., Simons, D.B., and Julien, P.Y., 1990, Highways in the river environment: Federal Highway Administration Publication FHWA-HI-90-016.

Ritter, D.F., 1984, Process Geomorphology: W.C. Brown Co., Debuque, Iowa, 603 p.

Shearman, J.O., 1990, User's manual for WSPRO--a computer model for water surface profile computations: Federal Highway Administration Publication FHWA-IP-89-027, 187 p.

Shearman, J.O., Kirby, W.H., Schneider, V.R., and Flippo, H.N., 1986, Bridge waterways analysis model; research report: Federal Highway Administration Publication FHWA-RD-86-108, 112 p.

Talbot, A.N., 1887, The determination of water-way for bridges and culverts.

U.S. Department of Transportation, 1993, Stream stability and scour at highway bridges, Participant Workbook: Federal Highway Administration Publication FHWA HI-91-011.

U.S. Geological Survey, 1973, Groton, Vermont 7.5 Minute Series quadrangle map: U.S. Geological Survey Topographic Maps, Scale $1: 24,000$. 


\section{APPENDIX A: \\ WSPRO INPUT FILE}




\section{WSPRO INPUT FILE}

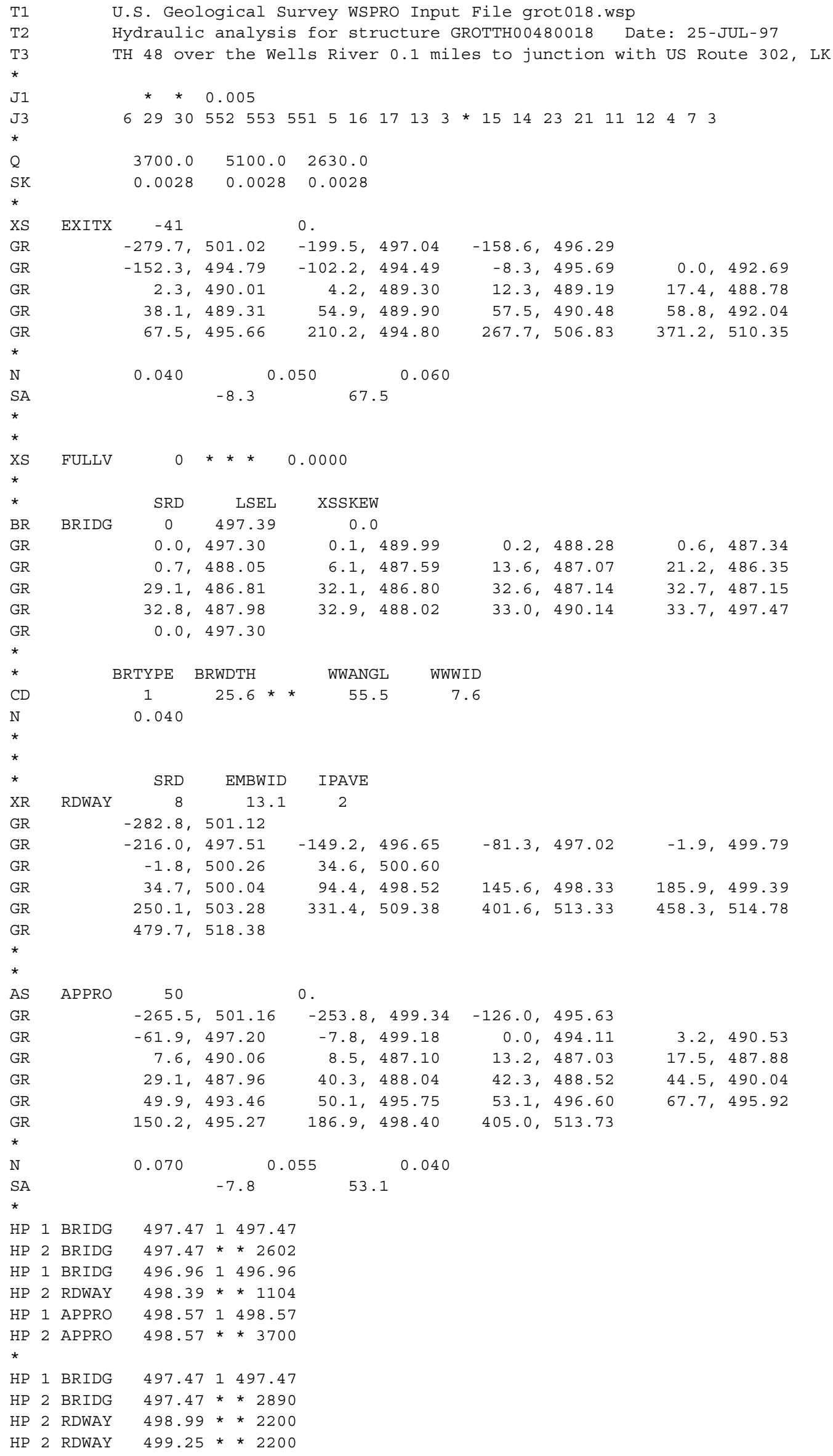




\section{APPENDIX B: \\ WSPRO OUTPUT FILE}




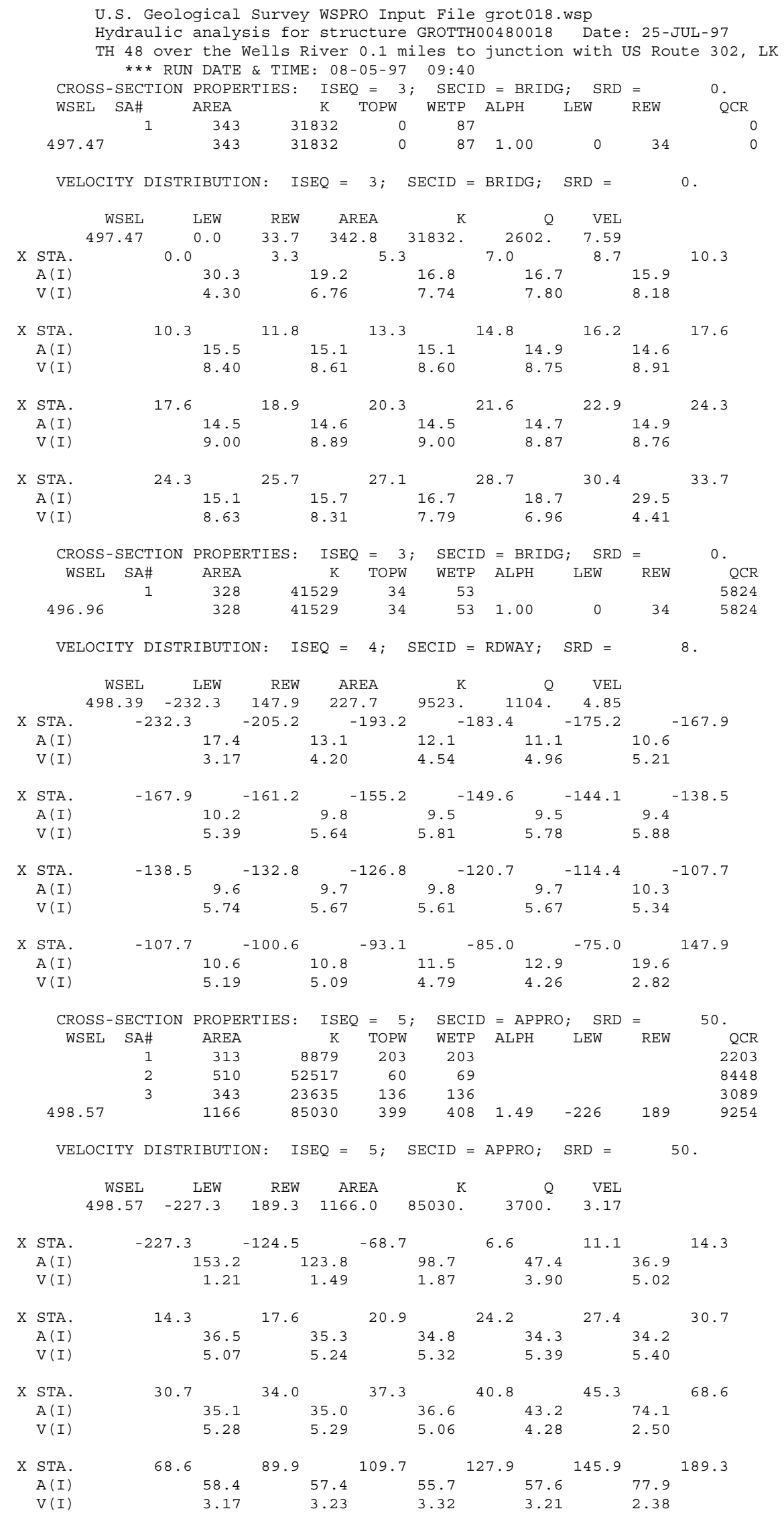


WSPRO OUTPUT FILE (continued)

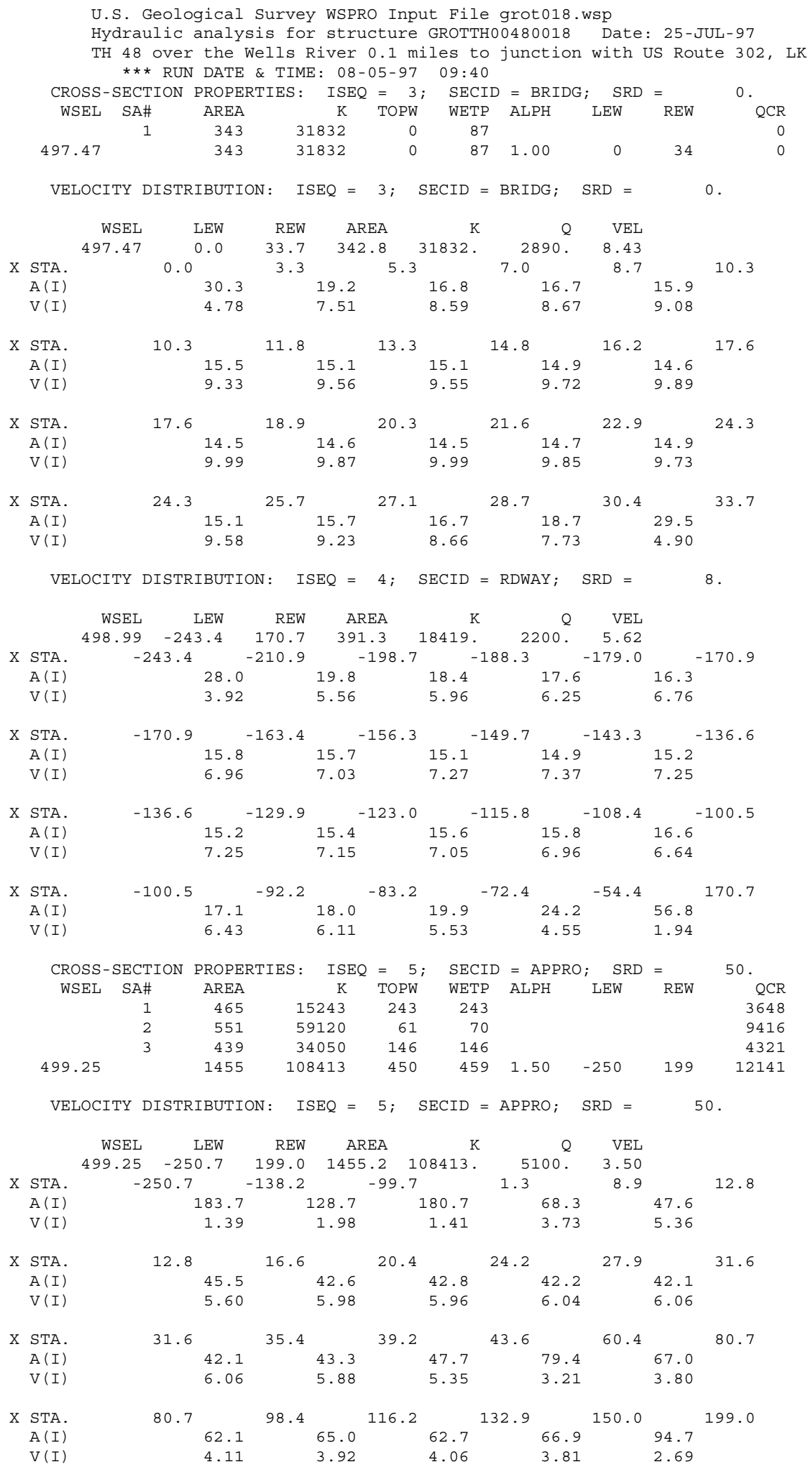


WSPRO OUTPUT FILE (continued)

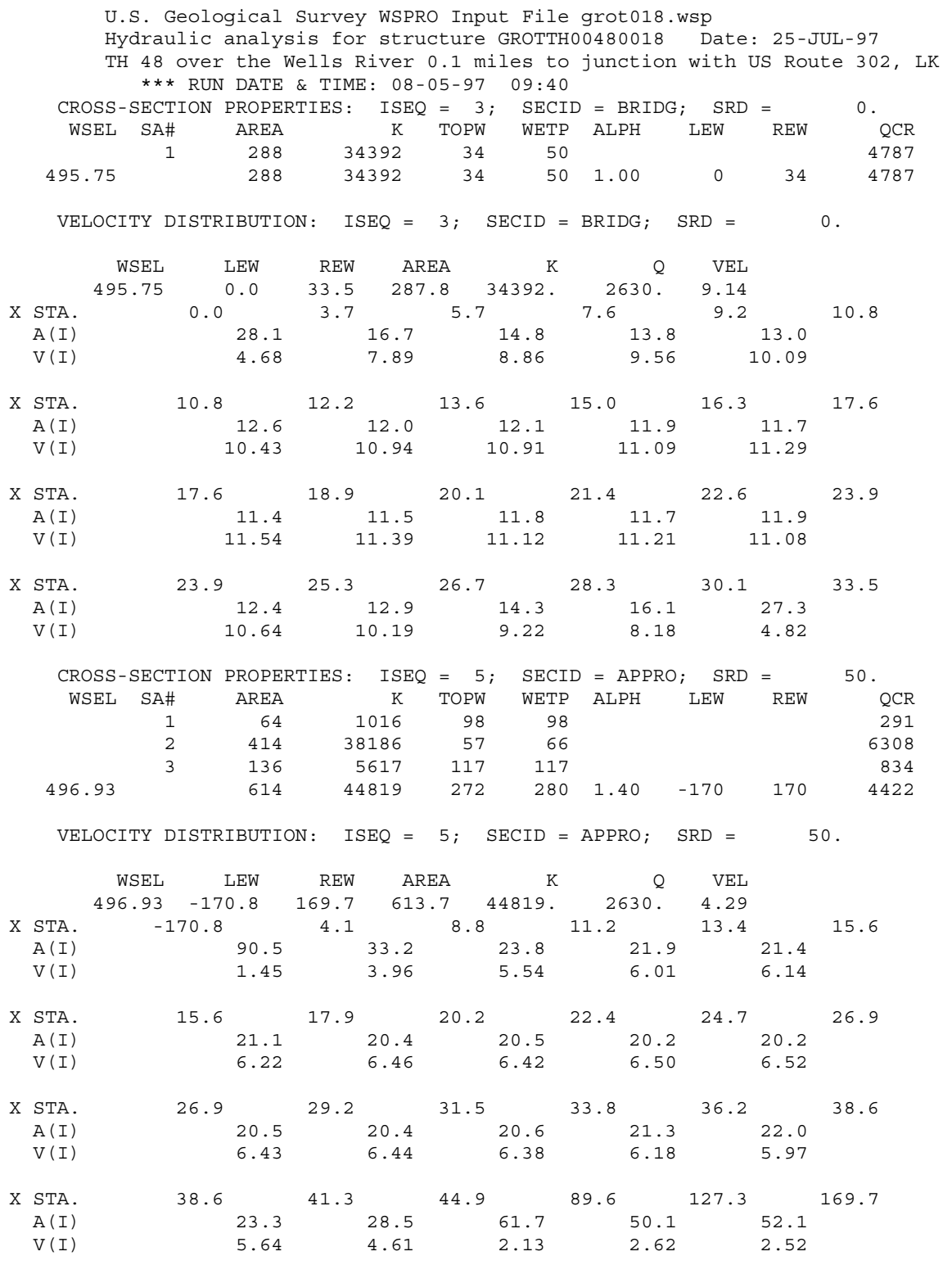


WSPRO OUTPUT FILE (continued)

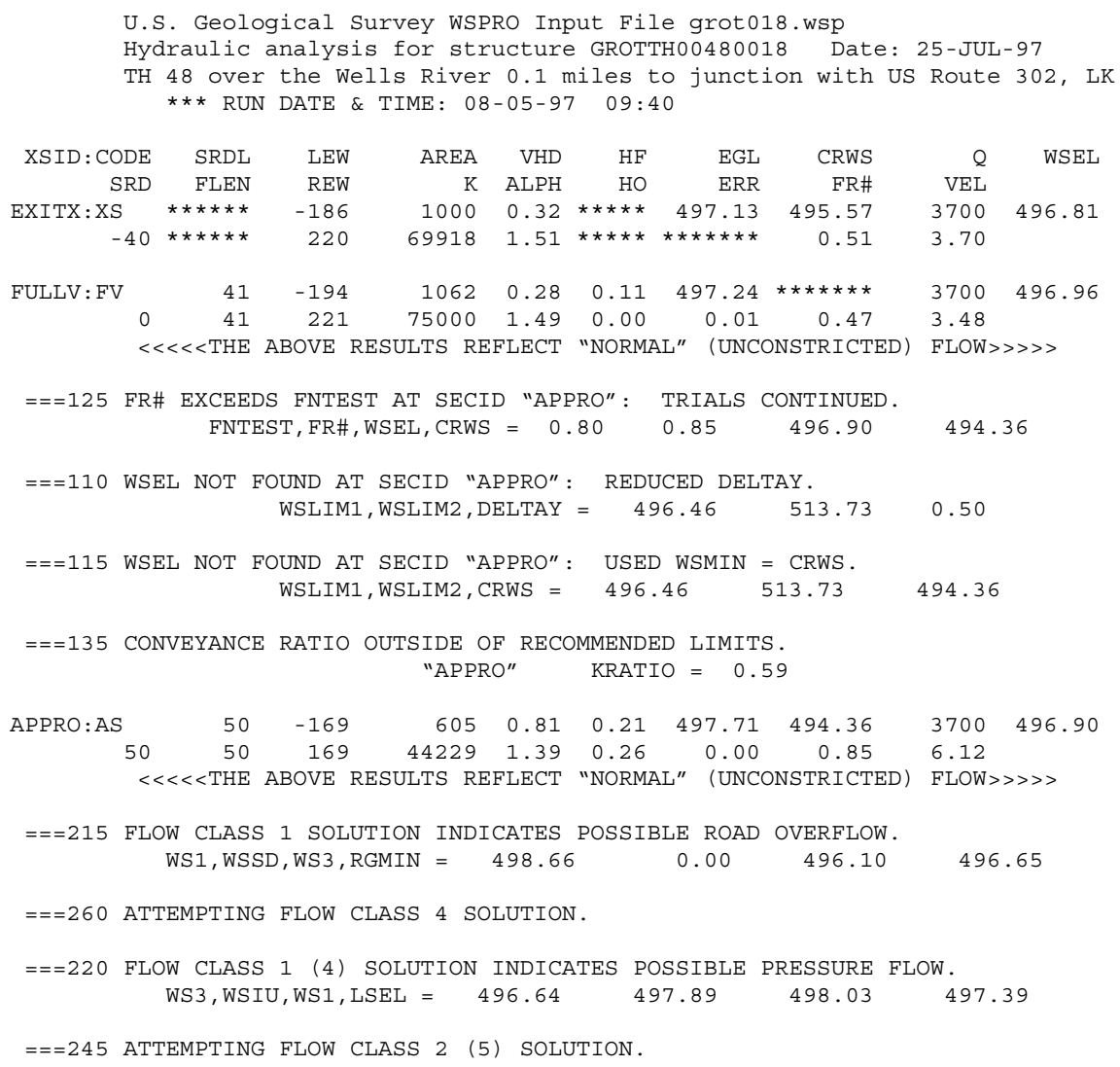


WSPRO OUTPUT FILE (continued)

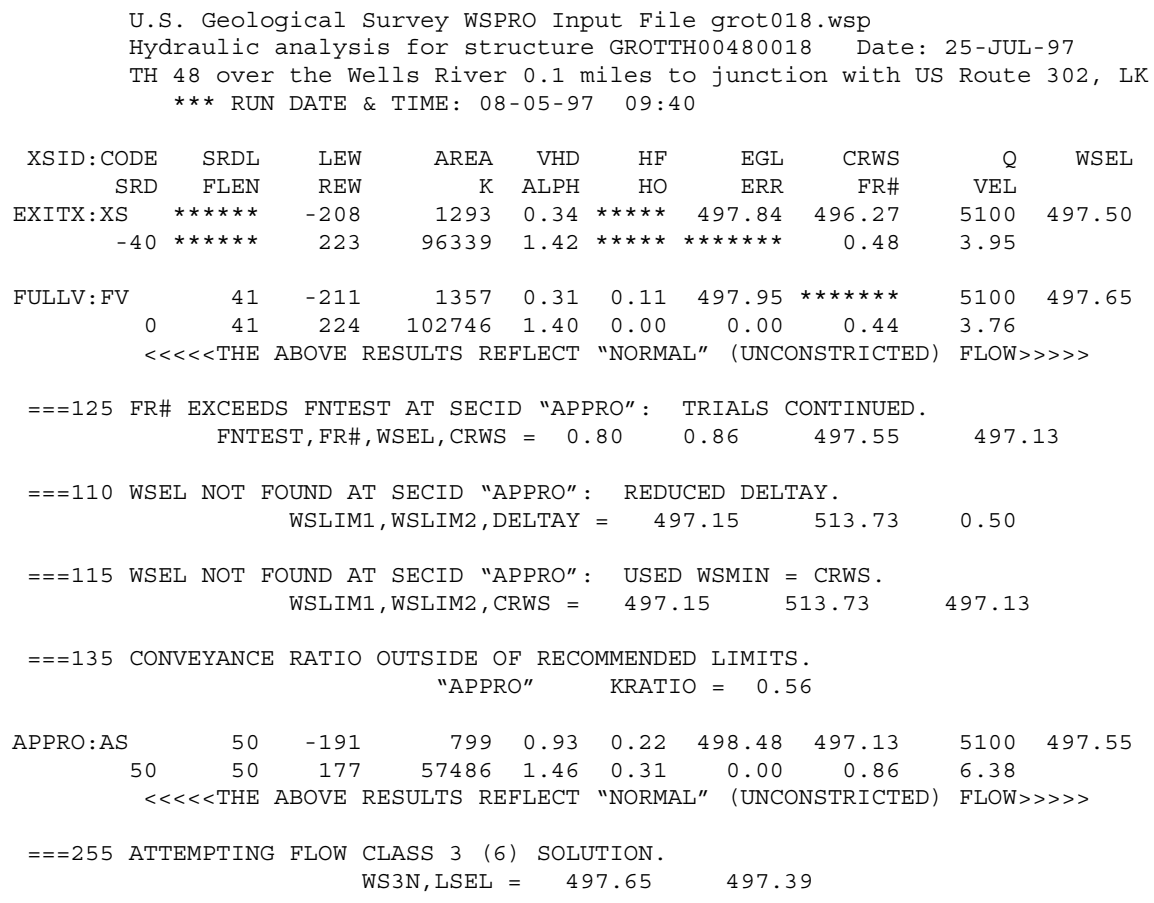

FIRST USER DEFINED TABLE.

\begin{tabular}{|c|c|c|c|c|c|c|c|c|}
\hline XSID: CODE & SRD & LEW & REW & $Q$ & $\mathrm{~K}$ & AREA & VEL & WSEL \\
\hline EXITX:XS & -41 & -209. & 223 . & 5100. & 96339. & 1293. & 3.95 & 497.50 \\
\hline FULLV : FV & 0 . & -212 . & 224 . & 5100. & 102746 . & 1357. & 3.76 & 497.65 \\
\hline BRIDG : BR & 0 . & 0 . & 34. & 2890 . & 31832 . & 343. & 8.43 & 497.47 \\
\hline RDWAY : RG & 8. & $\star \star \star \star \star \star *$ & 1970. & 2200 . & 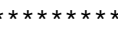 & $* * * * *$ & 2.00 & 498.99 \\
\hline APPRO: AS & 50. & -251 & 199. & 5100. & 108374 . & 1455. & 3.51 & 499.25 \\
\hline
\end{tabular}

SECOND USER DEFINED TABLE.

$\begin{array}{lcrrrrrrrr}\text { XSID : CODE } & \text { CRWS } & \text { FR\# } & \text { YMIN } & \text { YMAX } & \text { HF } & \text { HO } & \text { VHD } & \text { EGL } & \text { WSEL } \\ \text { EXITX : XS } & 496.27 & 0.48 & 488.78 & 510.35 * * * * * * * * * * & 0.34 & 497.84 & 497.50 \\ \text { FULLV : FV } & * * * * * * * * & 0.44 & 488.78 & 510.35 & 0.11 & 0.00 & 0.31 & 497.95 & 497.65 \\ \text { BRIDG : BR } & 493.28 & 0.47 & 486.35 & 497.47 * * * * * * * * * * * & 1.11 & 498.58 & 497.47 \\ \text { RDWAY : RG } & * * * * * * * * * * * * * * * * & 496.65 & 518.38 & 0.08 * * * * * * & 0.29 & 499.45 & 498.99 \\ \text { APPRO : AS } & 497.13 & 0.42 & 487.03 & 513.73 & 0.16 & 0.15 & 0.29 & 499.54 & 499.25\end{array}$


WSPRO OUTPUT FILE (continued)

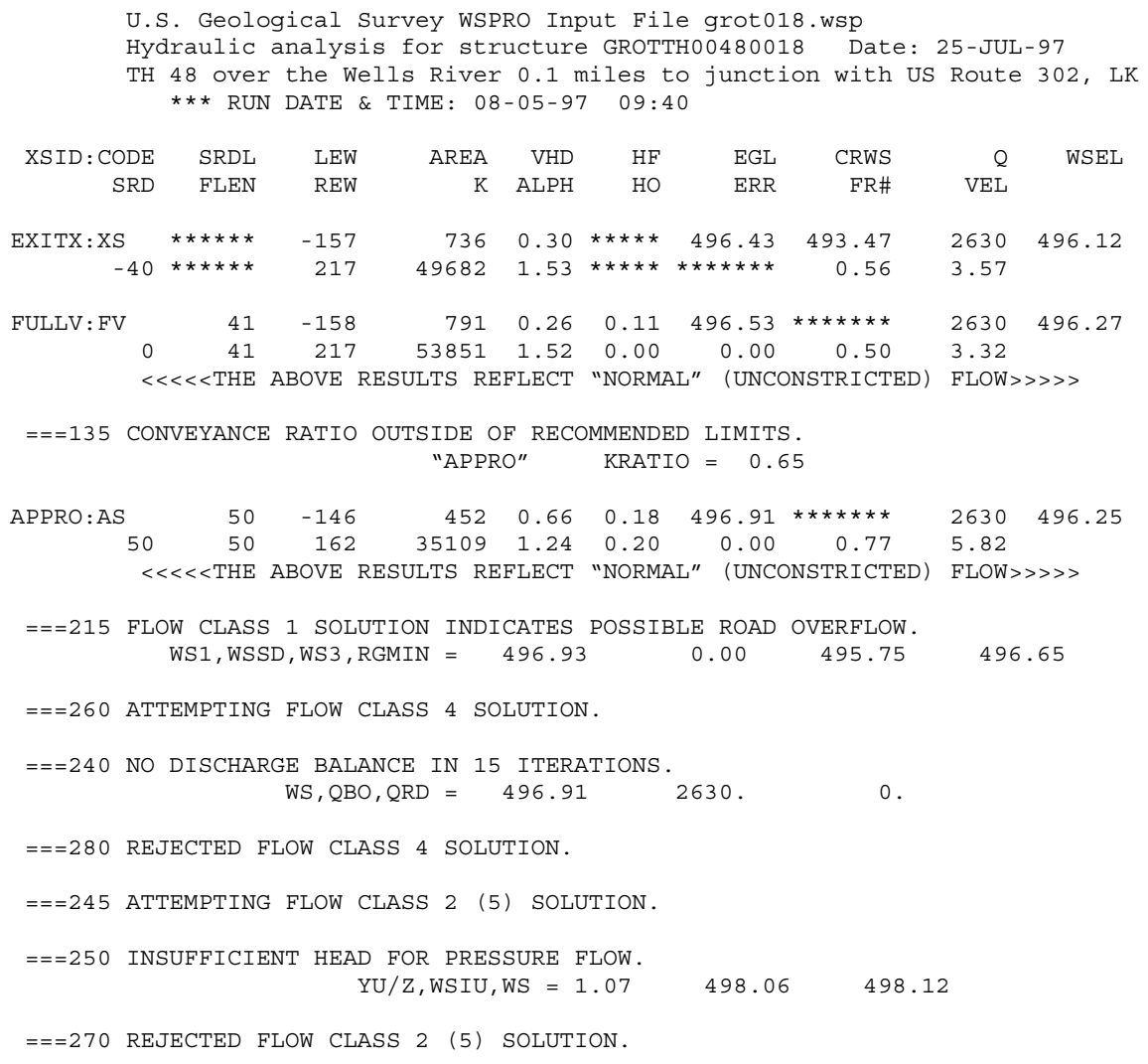




\section{APPENDIX C:}

\section{BED-MATERIAL PARTICLE-SIZE DISTRIBUTION}




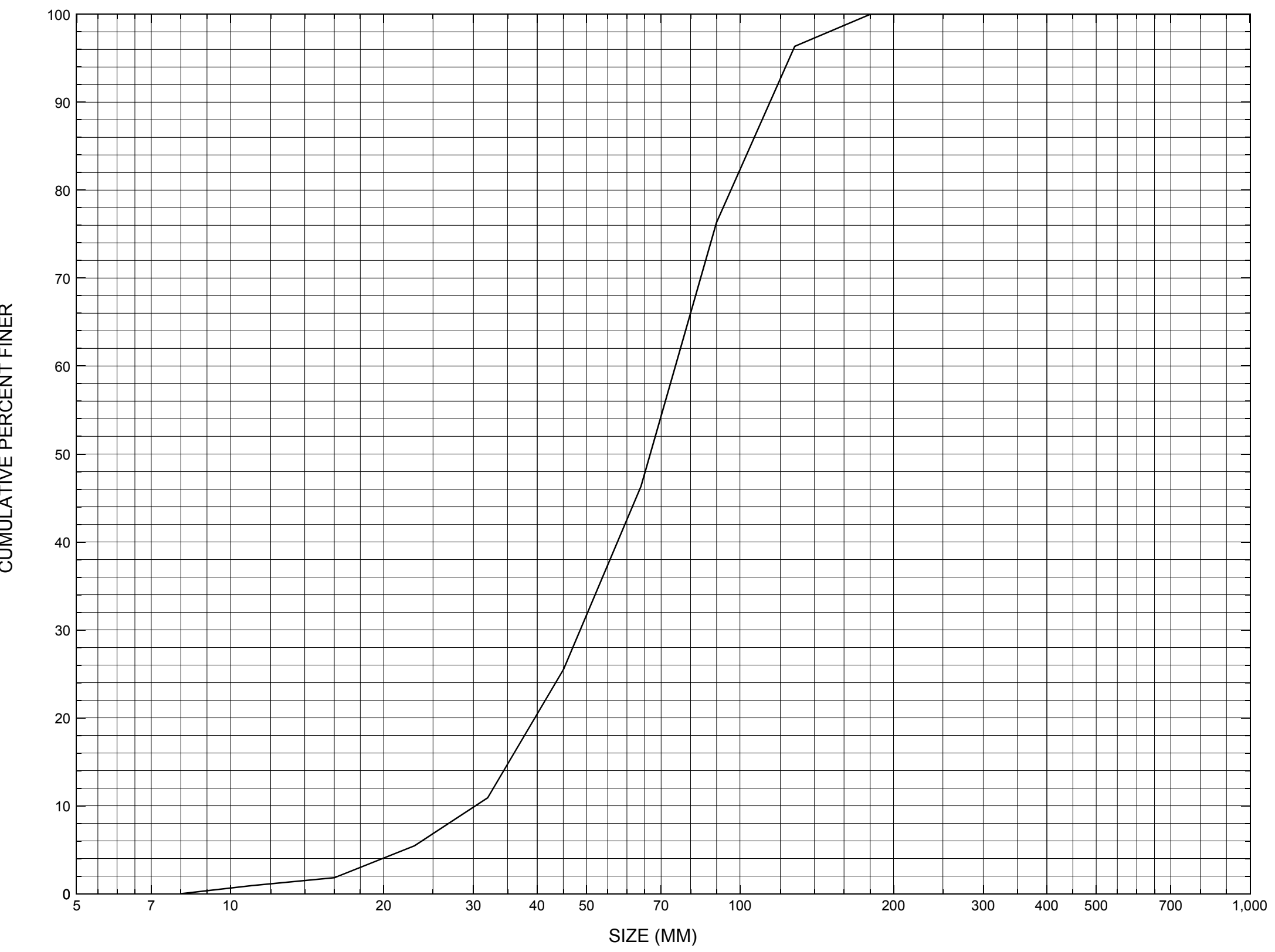

Appendix C. Bed material particle-size distribution for a pebble count in the channel approach of structure GROTTH00480018, in Groton, Vermont. 


\section{APPENDIX D: \\ HISTORICAL DATA FORM}




\section{Structure Number GROTTH00480018}

\section{General Location Descriptive}

Data collected by (First Initial, Full last name) $\mathbf{E}$. BOEHMLER

Date $(M M / D D / Y Y) \_\mathbf{0 3} / \underline{24} / \underline{95}$

Highway District Number (I - 2; nn) $\mathbf{0 7}$

Town (FIPS place code; I - 4; nnnnn) $\mathbf{3 0 5 5 0}$

Waterway (I - 6) WELLS RIVER

Route Number TH048

Topographic Map Groton

Latitude (I - 16; nnnn.n) $\mathbf{4 4 1 2 8}$
County (FIPS county code; I - 3; nnn)

Mile marker (I - 11; nnn.nnn) $\mathbf{0 0 0 0 0 0}$

Road Name (I - 7): -

Vicinity (I - 9) 0.1 MI JCT TH $48+$ US302

Hydrologic Unit Code: $\mathbf{0 1 0 8 0 1 0 2}$

Longitude (i - 17; nnnnn.n) $\mathbf{7 2 1 2 6}$

\section{Select Federal Inventory Codes}

FHWA Structure Number $(I-8) \quad \mathbf{1 0 0 3 0 4 0 0 1 8 0 3 0 4}$

Maintenance responsibility $(I-21 ; n n) \quad \mathbf{0 3} \quad$ Maximum span length $(I-48$; $n n n n) \underline{0036}$

Year built (I - 27; YYYY) 1963

Structure length (I - 49; nnnnnn) $\underline{\mathbf{0 0 0 0 3 8}}$

Average daily traffic, ADT (I - 29; nnnnnn) 000020 Deck Width (I - 52; nn.n) 131

Year of ADT (I - 30; YY) $\mathbf{9 3}$

Channel \& Protection $(I-61 ; n) \underline{5}$

Opening skew to Roadway $(I-34 ; n n) \quad \mathbf{0 0}$

Waterway adequacy $(I-71 ; n)$

Operational status $(I-41 ; X)$ A

Underwater Inspection Frequency $(I-92 B ; X Y Y) \_\mathbf{N}$

Structure type (I - 43; nnn) $\mathbf{3 0 3}$

Year Reconstructed (I - 106) $\mathbf{0 0 0 0}$

Approach span structure type (I - 44; nnn) $\mathbf{0 0 0}$ Clear span (nnn.n ft) _ _

Number of spans (I - 45; nnn) $\mathbf{0 0 1}$

Vertical clearance from streambed (nnn.n ft) $\underline{\mathbf{0 1 0 . 0}}$

Number of approach spans (I - 46; nnnn) $\mathbf{0 0 0 0}$

Waterway of full opening $\left(n n n . n \mathrm{ft}^{2}\right)$

Comments:

The structural inspection report of 6/29/93 indicates that the structure is a steel girder and floor beam system type bridge with a concrete deck and an asphalt roadway surface. The abutment walls and wingwalls are concrete. The wingwalls are extended with "laid-up" stone block walls. The report indicates the channel is scoured 2 to 3.5 feet below the water surface at each abutment footing. Both footings are exposed, but not undermined and no settlement is reported. The channel banks are reported as showing evidence of erosion from previous flooding. Point bars and debris accumulation are reported as minor at this bridge site. 


\section{Bridge Hydrologic Data}

Is there hydrologic data available? if No, type ctrl-n $h \quad$ VTAOT Drainage area $\left(\mathrm{mi}^{2}\right)$ : -

Terrain character:

Stream character \& type: -

Streambed material:

Discharge Data (cfs):

$$
\begin{aligned}
& Q_{2.33}- \\
& Q_{50}-
\end{aligned}
$$

Record flood date $(M M / D D / Y Y)$ :

Estimated Discharge (cfs): Ice conditions (Heavy, Moderate, Light) : -

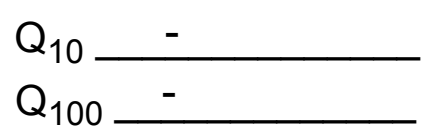

$$
\begin{aligned}
& Q_{25}- \\
& Q_{500}-
\end{aligned}
$$

Water surface elevation (ft): $(\mathrm{ft} / \mathrm{s}):$

The stage increases to maximum highwater elevation (Rapidly, Not rapidly):

The stream response is (Flashy, Not flashy):

Describe any significant site conditions upstream or downstream that may influence the stream's stage: -

Watershed storage area (in percent): _ _ \%

The watershed storage area is: - (1-mainly at the headwaters; 2- uniformly distributed; 3-immediatly upstream oi the site)

Water Surface Elevation Estimates for Existing Structure:

\begin{tabular}{|l|l|l|l|l|l|}
\hline Peak discharge frequency & $Q_{2.33}$ & $Q_{10}$ & $Q_{25}$ & $Q_{50}$ & $Q_{100}$ \\
Water surface elevation (ft)) & - & - & - & - & - \\
Velocity (ft/sec) & - & - & - & - & - \\
\hline
\end{tabular}

Long term stream bed changes: -

Is the roadway overtopped below the $\mathrm{Q}_{100}$ ? (Yes, No, Unknown): $\mathbf{U}$ Frequency: Relief Elevation $(f t)$ : Discharge over roadway at $Q_{100}\left(f^{3} / \mathrm{sec}\right)$ :

Are there other structures nearby? (Yes, No, Unknown): $\underline{\mathbf{U}}$ Upstream distance (miles): Town: If No or Unknown, type ctrl-n os Highway No. : Structure No. : Year Built:

Clear span (ft): Clear Height $(f t)$ : Full Waterway $\left(f^{2}\right)$ : 
Downstream distance (miles): Town: Year Built:

Highway No. : Structure No. : Structure Type:

Clear span (ft): Clear Height $(f t)$ : Full Waterway $\left(f^{2}\right)$ : -

Comments:

\section{USGS Watershed Data}

Watershed Hydrographic Data

Drainage area $(D A) \stackrel{53.65}{\mathrm{mi}^{2}}$

Watershed storage (ST) 3.9

Bridge site elevation 800 Main channel length 11.34 $\mathrm{mi}^{2}$ Lake/pond/swamp area 2.08 $\mathrm{mi}^{2}$ $10 \%$ channel length elevation $\mathbf{9 0 0}$ $\%$ $10 \%$ channel length elevation $\mathrm{ft}$

Headwater elevation 2369 $\mathrm{ft}$ mi

Main channel slope $(S)$
(S) 81.72 $\mathrm{ft} / \mathrm{mi}$

Watershed Precipitation Data

Average site precipitation in Average headwater precipitation in

Maximum 2yr-24hr precipitation event $(124,2)$ in

Average seasonal snowfall (Sn) $\mathrm{ft}$ 


\section{Bridge Plan Data}

Are plans available? $\mathbf{N} \quad$ If no, type ctrl-n pl Date issued for construction (MM / YYYY):

Project Number

Minimum channel bed elevation:

Low superstructure elevation: USLAB DSLAB USRAB DSRAB Benchmark location description:

There is no benchmark information available.

Reference Point (MSL, Arbitrary, Other): Datum (NAD27, NAD83, Other):

Foundation Type: 4

If 1: Footing Thickness

If 2: Pile Type: (1-Wood; 2-Steel or metal; 3-Concrete)

(1-Spreadfooting; 2-Pile; 3- Gravity; 4-Unknown)

If 3 : Footing bottom elevation:

Is boring information available? $\mathbf{N}$ If no, type ctrl-n bi Number of borings taken:

Foundation Material Type: $\mathbf{3}$ (1-regolith, 2-bedrock, 3-unknown)

Briefly describe material at foundation bottom elevation or around piles:

There is no foundation material information available.

Comments:

There are no plans available. 


\section{Cross-sectional Data}

Is cross-sectional data available? $\underline{\mathbf{Y}}$ If no, type ctrl-n xs

Source (FEMA, VTAOT, Other)? VTAOT

Comments: This is a cross section of the upstream face. The low chord elevation is from the survey log done for this report on $08 / 28 / 95$. The low chord to bed length data is from the sketch attached to a bridge inspection report dated $06 / 29 / 93$.

\begin{tabular}{|l|l|l|l|l|l|l|l|l|l|l|l|}
\hline Station & $\mathbf{0}$ & $\mathbf{2}$ & $\mathbf{1 9}$ & $\mathbf{3 0 . 6}$ & $\mathbf{3 2 . 6}$ & - & - & - & - & - & - \\
\hline Feature & LAB & - & - & - & RAB & - & - & - & - & - & - \\
\hline $\begin{array}{l}\text { Low chord } \\
\text { elevation }\end{array}$ & $\mathbf{4 9 7 . 3}$ & $\mathbf{4 9 7 . 3}$ & $\mathbf{4 9 7 . 4}$ & $\mathbf{4 9 7 . 5}$ & $\mathbf{4 9 7 . 5}$ & - & - & - & - & - & - \\
\hline $\begin{array}{l}\text { Bed } \\
\text { elevation }\end{array}$ & - & $\mathbf{4 8 6 . 4}$ & $\mathbf{4 8 6 . 3}$ & $\mathbf{4 8 8 . 0}$ & - & - & - & - & - & - & - \\
\hline $\begin{array}{l}\text { Low chord- } \\
\text { bed }\end{array}$ & - & $\mathbf{1 0 . 9}$ & $\mathbf{1 1 . 1}$ & $\mathbf{9 . 5}$ & - & - & - & - & - & - & - \\
\hline Station & - & - & - & - & - & - & - & - & - & - & - \\
\hline Feature & - & - & - & - & - & - & - & - & - & - & - \\
\hline $\begin{array}{l}\text { Low chord } \\
\text { elevation }\end{array}$ & - & - & - & - & - & - & - & - & - & - & - \\
\hline $\begin{array}{l}\text { Bed } \\
\text { elevation }\end{array}$ & - & - & - & - & - & - & - & - & - & - & - \\
\hline $\begin{array}{l}\text { Low chord- } \\
\text { bed }\end{array}$ & - & - & - & - & - & - & - & - & - & - & - \\
\hline
\end{tabular}

Source (FEMA, VTAOT, Other)?

Comments:

\begin{tabular}{|l|l|l|l|l|l|l|l|l|l|l|l|}
\hline Station & & - & - & - & - & - & - & - & - & - & - \\
\hline Feature & - & - & - & - & - & - & - & - & - & - & - \\
\hline $\begin{array}{l}\text { Low chord } \\
\text { elevation }\end{array}$ & - & - & - & - & - & - & - & - & - & - & - \\
\hline $\begin{array}{l}\text { Bed } \\
\text { elevation }\end{array}$ & - & - & - & - & - & - & - & - & - & - & - \\
\hline $\begin{array}{l}\text { Low chord- } \\
\text { bed }\end{array}$ & - & - & - & - & - & - & - & - & - & - & - \\
\hline Station & - & - & - & - & - & - & - & - & - & - & - \\
\hline Feature & - & - & - & - & - & - & - & - & - & - & - \\
\hline $\begin{array}{l}\text { Low chord } \\
\text { elevation }\end{array}$ & - & - & - & - & - & - & - & - & - & - & - \\
\hline $\begin{array}{l}\text { Bed } \\
\text { elevation }\end{array}$ & - & - & - & - & - & - & - & - & - & - & - \\
\hline $\begin{array}{l}\text { Low chord- } \\
\text { bed }\end{array}$ & - & - & - & - & - & - & - & - & - & - & - \\
\hline
\end{tabular}




\section{APPENDIX E: \\ LEVEL I DATA FORM}


U. S. Geological Survey

Bridge Field Data Collection and Processing Form

Qa/Qc Check by: EW

Date: $\mathbf{0 2 / 2 9 / 9 6}$

\section{Structure Number GROTTH00480018} Computerized by: $\underline{\mathbf{E W} \text { Date: } 02 / 29 / 96}$

Reviewd by: LKS Date: $\underline{\mathbf{0 8 / 0 5 / 9 7}}$

\section{A. General Location Descriptive}

1. Data collected by (First Initial, Full last name) L. MEDALIE

2. Highway District Number 07

County CALENDONIA 005

Mile marker $\mathbf{0}$

Waterway (I - 6) WELLS RIVER

Route Number TH048

Town GROTON

Road Name WELTON ROAD

Hydrologic Unit Code: $\mathbf{0 1 0 8 0 1 0 2}$

3. Descriptive comments:

Date $(M M / D D / Y Y) \underline{08} / \underline{\mathbf{2 8} / 1996}$

The bridge is located 0.1 miles from the junction with US Route 302.

\section{B. Bridge Deck Observations}
4. Surface cover... LBUS 5
RBUS 4
LBDS 4
RBDS 5
Overall 5

(2b us, ds,lb,rb: 1- Urban; 2- Suburban; 3- Row crops; 4- Pasture; 5- Shrub- and brushland; 6- Forest; 7- Wetland)
5. Ambient water surface... US 1
UB 1
DS 1
(1- pool; 2- riffle)

6. Bridge structure type 1 (1- single span; 2- multiple span; 3- single arch; 4- multiple arch; 5-cylindrical culvert; 6- box culvert; or 7- other)
7. Bridge length $\underline{\mathbf{3 8 . 0}}$
(feet)
Span length $\mathbf{3 6 . 0}$
(feet)
Bridge width 13.1 (feet)

\section{Road approach to bridge:}
8. LB 1 RB 1
( 0 even, 1- lower, 2- higher)
9. LB_2
RB $\underline{2}$
(1-Paved, 2- Not paved)

10. Embankment slope (run / rise in feet / foot)

US left

US right

\begin{tabular}{|c|c|c|c|}
\hline \multicolumn{2}{|c|}{ Protection } & \multirow{2}{*}{ 13.Erosion } & 14.Severity \\
\cline { 6 - 6 } & 12.Cond. & & \\
\hline $\mathbf{0}$ & - & $\mathbf{0}$ & - \\
\hline
\end{tabular}

LBUS

RBUS

RBDS

LBDS

\begin{tabular}{l}
0 \\
0 \\
\hline 0
\end{tabular}

Bank protection types: 0 - none; 1- $<12$ inches;

2- $<36$ inches; 3- $<48$ inches

4- < 60 inches; 5- wall / artificial levee

Bank protection conditions: 1- good; 2- slumped;

3- eroded; 4- failed

Erosion: 0 - none; 1- channel erosion; 2 -

road wash; 3- both; 4- other

Erosion Severity: 0 - none; 1- slight; 2- moderate; 3- severe

\section{Channel approach to bridge (BF):}

15. Angle of approach: $\mathbf{0}$

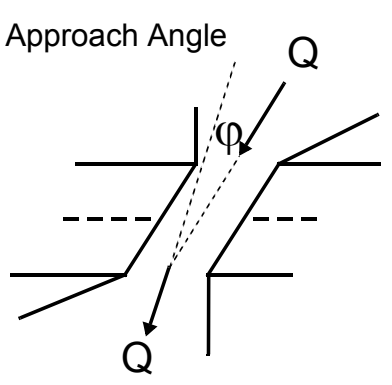

17. Channel impact zone 1 :

Where? RB (LB, RB)

Range? 65 feet US

Channel impact zone 2:

Where? (LB, RB)

Range? feet (US, UB, DS) to feet

16. Bridge skew: $\mathbf{0}$ Bridge Skew Angle

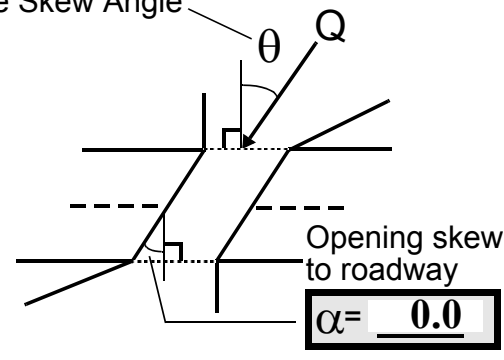

\section{Exist? $\mathbf{Y}(Y$ or $N)$}

Severity 1

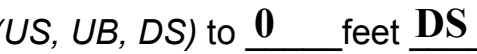

Exist? $\mathbf{N}(Y$ or $N)$

Severity

Impact Severity: 0- none to very slight; 1- Slight; 2- Moderate; 3- Severe 
18. Bridge Type: 1a

1a- Vertical abutments with wingwalls

1 b- Vertical abutments without wingwalls

2- Vertical abutments and wingwalls, sloping embankment

Wingwalls parallel to abut. face

3- Spill through abutments

4- Sloping embankment, vertical wingwalls and abutments

1a with wingwalls

Wingwall angle less than $90^{\circ}$.

19. Bridge Deck Comments (surface cover variations, measured bridge and span lengths, bridge type variations, approach overflow width, etc.)

\#7: Field measurements of bridge; measured span $=34.5$ feet; bridge length $=38.5$; bridge width $=$ 15 feet; bridge width= 13 feet (between the curbs).

\section{Upstream Channel Assessment}

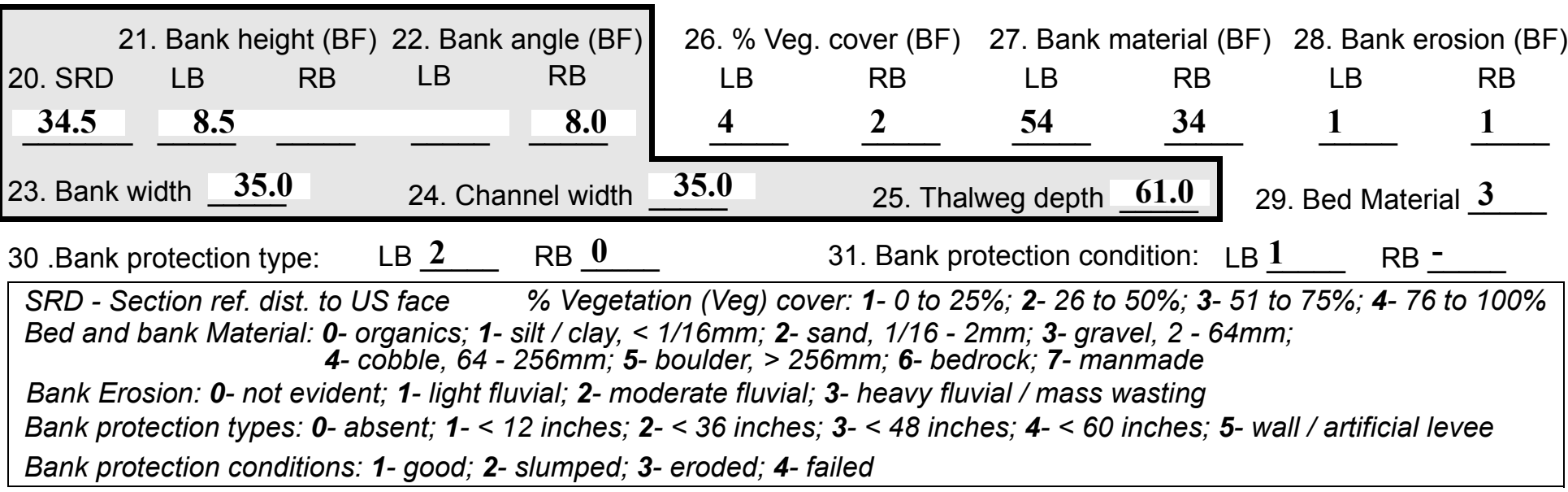

32. Comments (bank material variation, minor inflows, protection extent, etc.):

\#26: RB two large trees between US bridge face and 90 feet US

\#30: LB protection extends from US bridge face to 95 feet US 
33.Point/Side bar present? $\mathbf{N}(Y$ or $N$. if $N$ type ctrl-n pb)34. Mid-bar distance: -

35. Mid-bar width: -

36. Point bar extent: feet (US, UB) to feet (US, UB, DS) positioned $\%$ LB to $\% \mathrm{RB}$

37. Material: -

38. Point or side bar comments (Circle Point or Side; Note additional bars, material variation, status, etc.):

There are no pointbars upstream at this site.

US from where channel scour begins (US 90 feet), the series of alternating cobble/gravel side bars between LB and RB terminates. The bridge deck photo looking US clearly shows this feature.

39. Is a cut-bank present? $\mathbf{N}$ ( $Y$ or if $N$ type $c$ trl-n $c b)$

40. Where? (LB or $R B)$

41. Mid-bank distance: -

42. Cut bank extent: feet (US, UB) to feet (US, UB, DS)

43. Bank damage: (1- eroded and/or creep; 2- slip failure; 3- block failure)

44. Cut bank comments (eg. additional cut banks, protection condition, etc.):

There are no cut-banks upstream at this site.

Note: There are some leaning trees US in the bridge deck photo of US.

\section{Is channel scour present? $\mathbf{Y}$ ( $Y$ or if $N$ type ctrl-n cs)}

47. Scour dimensions: Length $\mathbf{9 0}$ Width $\underline{34.5}$ Depth : 2

46. Mid-scour distance: 0 *

48. Scour comments (eg. additional scour areas, local scouring process, etc.):

Scour begins 90 feet US and continues under bridge to 50 feet DS. The total length of the scour hole is 155 feet.

The mid-scour distance is located at the US bridge face.

\section{Are there major confluences? $\mathbf{N}$} (Y or if $N$ type ctrl-n $m c)$

51. Confluence 1: Distance 52. Enters on Enters on - $\quad(L B$ or $R B)$ Confluence 2: Distance 54. Confluence comments (eg. confluence name):

There are no major confluences upstream at this site.

\section{Under Bridge Channel Assessment}

55. Channel restraint (BF)? LB 2 (1- natural bank; 2- abutment; 3- artificial levee)

\begin{tabular}{|ccccc}
\multicolumn{2}{|c}{56. Height (BF) } & \multicolumn{3}{c}{57 Angle (BF) } \\
LB & RB & LB & RB \\
$\mathbf{3 9 . 0}$ & & & $\mathbf{2 . 0}$ & \\
\hline
\end{tabular}

58. Bank width (BF) -

59. Channel width 61. Material (BF) LB RB 62. Erosion (BF)

$2 \quad 7$
LB RB

Bed and bank Material: 0- organics; 1- silt / clay, < 1/16mm; 2- sand, 1/16 - 2mm; 3- gravel, 2 - 64mm; 4- cobble, 64 - 256mm; 5- boulder, > 256mm; 6- bedrock; 7- manmade

Bank Erosion: 0- not evident; 1- light fluvial; 2- moderate fluvial; 3- heavy fluvial / mass wasting

64. Comments (bank material variation, minor inflows, protection extent, etc.):

3 
65. Debris and Ice Is there debris accumulation?

$(Y$ or $N)$ 66. Where? $\mathbf{N}$

(1- Upstream; 2- At bridge; 3- Both)

67. Debris Potential ( 1-Low; 2- Moderate; 3- High)

68. Capture Efficiency 1 (1-Low; 2- Moderate; 3- High)

69. Is there evidence of ice build-up? 1 (Y or $N)$

Ice Blockage Potential $\mathbf{N}$

(1-Low; 2- Moderate; 3- High)

70. Debris and Ice Comments:

1

Although the debris potential is noted as low, there are some trees US leaning into the stream.

\begin{tabular}{|l|c|c|c|c|c|c|c|c|}
\hline Abutments & $\begin{array}{c}\text { 71. Attack } \\
\angle \text { (BF) }\end{array}$ & $\begin{array}{c}\text { 72. Slope } \angle \\
\text { (Qmax) }\end{array}$ & $\begin{array}{c}\text { 73. Toe } \\
\text { loc. (BF) }\end{array}$ & $\begin{array}{c}\text { 74. Scour } \\
\text { Condition }\end{array}$ & $\begin{array}{c}75 . \text { Scour } \\
\text { depth }\end{array}$ & $\begin{array}{c}\text { 76. Exposure } \\
\text { depth }\end{array}$ & 77. Material & 78. Length \\
\hline LABUT & & $\mathbf{0}$ & $\mathbf{9 0}$ & $\mathbf{2}$ & $\mathbf{3}$ & $\mathbf{3 . 2 5}$ & $\mathbf{1 . 2 5}$ & $\mathbf{9 0 . 0}$ \\
\hline RABUT & $\mathbf{1}$ & $\mathbf{0}$ & $\mathbf{9 0}$ & & & $\mathbf{2}$ & $\mathbf{3}$ & $\mathbf{3 2 . 5}$ \\
\hline
\end{tabular}

Pushed: $L B$ or RB

Toe Location (Loc.): 0- even, 1- set back, 2- protrudes

Scour cond.: 0- not evident; 1- evident (comment); 2- footing exposed; 3-undermined footing; 4- piling exposed; 5- settled; 6- failed

Materials: 1- Concrete; 2- Stone masonry or drywall; 3- steel or metal; 4- wood

79. Abutment comments (eg. undermined penetration, unusual scour processes, debris, etc.):

3.25

1.25

1

RABUT: the footing is undermined at the US end (at the suture between WW and abutment).

LABUT: the footing is undermined at the US end (at the suture between WW and abutment).

The undermining of both abutments is minimal. The bottom of the footing is exposed about 2 feet on the left and right abutment.

80. Wingwalls:

$\begin{array}{lllll} & & & & \\ \text { Exist? } & \text { Material? } & \text { Scour } & \text { Scour } & \text { Exposure } \\ \text { Condition? } & \text { depth? } & \text { depth? }\end{array}$

USLWW:

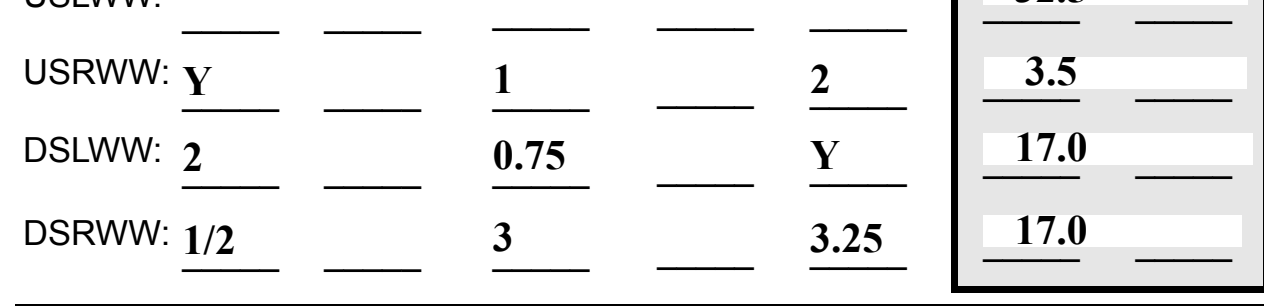

Wingwall materials: 1- Concrete; 2- Stone masonry or drywall; 3- steel or metal; 4- wood

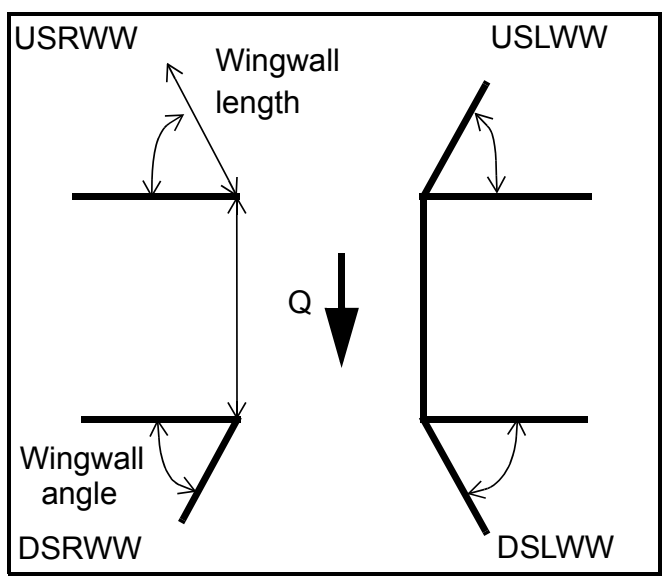

82. Bank / Bridge Protection:

\begin{tabular}{|l|l|l|l|l|l|l|c|c|}
\hline Location & USLWW & USRWW & LABUT & RABUT & LB & RB & DSLWW & DSRWW \\
\hline Type & $\mathbf{1 . 2 5}$ & $\mathbf{2}$ & Y & $\mathbf{0}$ & $\mathbf{1}$ & - & - & - \\
\hline Condition & $\mathbf{Y}$ & $\mathbf{2}$ & $\mathbf{1} / \mathbf{2}$ & $\mathbf{0}$ & $\mathbf{1}$ & - & - & - \\
\hline Extent & $\mathbf{1} / \mathbf{2}$ & $\mathbf{0 . 7 5}$ & $\mathbf{1}$ & $\mathbf{1}$ & $\mathbf{0}$ & $\mathbf{0}$ & $\mathbf{0}$ & $\mathbf{0}$ \\
\hline
\end{tabular}

Bank / Bridge protection types: 0- absent; 1- < 12 inches; 2- < 36 inches; 3- < 48 inches; 4- < 60 inches; 
83. Wingwall and protection comments (eg. undermined penetration, unusual scour processes, etc.):

-
-
0
-
-
0
-
-
2
1
1

\section{Piers:}

84. Are there piers? US (Y or if $N$ type ctrl-n pr)

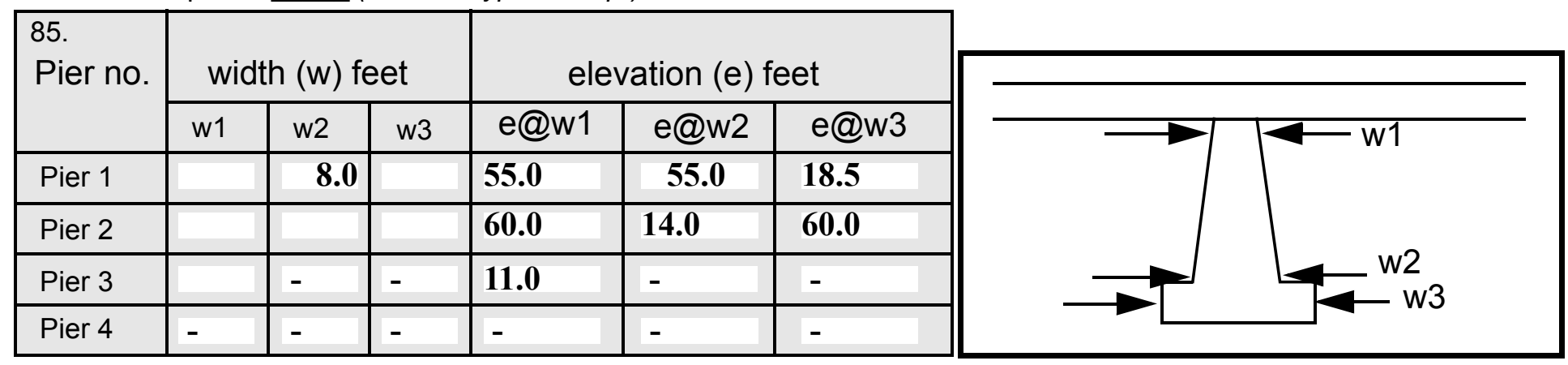

\begin{tabular}{|l|l|l|l|l|}
\hline Level 1 Pier Descr. & \multicolumn{1}{|c|}{1} & \multicolumn{1}{|c|}{2} & \multicolumn{1}{|c|}{3} & \multicolumn{1}{|c|}{4} \\
\hline 86. Location (BF) & RWW: & for & 5 feet & expose \\
\hline 87. Type & con- & anot & of & d. \\
\hline 88. Material & crete & her & wing & DSR \\
\hline 89. Shape & first & $\mathbf{1 0}$ & wall. & WW \\
\hline 90. Inclined? & $\mathbf{1 0}$ & feet. & The & and \\
\hline 91. Attack $\angle$ (BF) & feet, & The & entir & DSL \\
\hline 92. Pushed & then & foot- & e & WW \\
\hline 93. Length (feet) & - & - & - & - \\
\hline 94. \# of piles & piled & ing & lengt & : \\
\hline 95. Cross-members & gran & exist & h of & con- \\
\hline 96. Scour Condition & ite & s for & the & crete \\
\hline 97. Scour depth & bloc & the & foot- & for \\
\hline 98. Exposure depth & ks & first & ing is & first \\
\hline
\end{tabular}

LFP, LTB, LB, MCL, MCM, MCR, RB, RTB, RFP

1- Solid pier, 2- column, 3- bent

1-Wood; 2- concrete; 3- metal; 4- stone

1- Round; 2- Square; 3- Pointed

Y-yes; $N-$ no

$L B$ or $R B$

0- none; 1- laterals; 2- diagonals; 3- both

0- not evident; 1- evident (comment);

2- footing exposed; 3- piling exposed;

4- undermined footing; 5- settled; 6- failed 
99. Pier comments (eg. undermined penetration, protection and protection extent, unusual scour processes, etc.):

6 feet, then dry quarried granite blocks for at least 10 feet. At the stream end of both DSRWW and DSLWW

- top exposed of concrete footing.

$\mathbf{N}$

100.

\section{E. Downstream Channel Assessment}

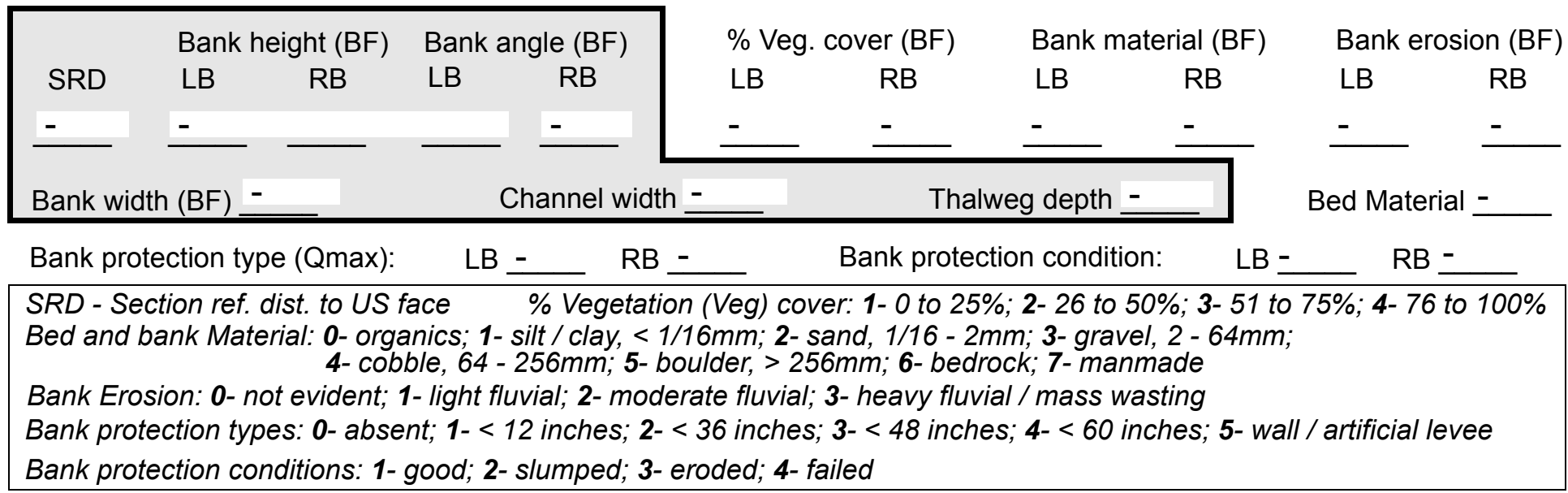

Comments (eg. bank material variation, minor inflows, protection extent, etc.):

$-$

-

-

-

-

-

$-$

-

-

-

$-$

-

-

101. Is a drop structure present? _ ( $Y$ or $N$, if $N$ type ctrl-n ds) 102. Distance: ___ feet
103. Drop: - feet
104. Structure material: -
(1- steel sheet pile; 2- wood pile; 3- concrete; 4- other)

105. Drop structure comments (eg. downstream scour depth):

-

-

-

-

-

$-$ 
106. Point/Side bar present? (Y or $N$. if $N$ type ctrl-n pb)Mid-bar distance:

Mid-bar width: -

Point bar extent: feet -

(US, UB, DS) to feet (US, UB, DS) positioned $\%$ LB to $\% \mathrm{RB}$ Material:

Point or side bar comments (Circle Point or Side; note additional bars, material variation, status, etc.):

S a cut-bank present? Th (Y or if $N$ type ctrl- $n c b) \quad$ Where? ere (LB or RB) Mid-bank distance: are Cut bank extent: no feet pie (US, UB, DS) to rs at feet this (US, UB, DS)

Bank damage: bri (1- eroded and/or creep; 2- slip failure; 3- block failure)

Cut bank comments (eg. additional cut banks, protection condition, etc.): dge.

Is channel scour present? (Y or if $N$ type ctrl-n cs)

Mid-scour distance:

Scour dimensions: Length Width Depth:

Positioned $\%$ LB to $\underline{3} \%$ RB Scour comments (eg. additional scour areas, local scouring process, etc.): 3

1

Are there major confluences? 1 ( $Y$ or if $N$ type ctrl-n $m c)$ Confluence 1: Distance 2 Enters on $\underline{\mathbf{2}}$ (LB or RB) How many? $3 / \mathbf{2} / \mathbf{4}$

Confluence 2: Distance 1 Enters on Ban (LB or RB)

Type 1 (1-perennial; 2- ephemeral) Confluence comments (eg. confluence name):

Type $\underline{\mathbf{k}}$ (1- perennial; 2- ephemeral)

material: sand layer on top of cobble layer (base).

LB protection starts at end of dry masonry end of LB DSWW to beyond 200 feet DS.

\section{F. Geomorphic Channel Assessment}

$\begin{array}{ll}\text { 107. Stage of reach evolution } \mathbf{R B} & \mathbf{1 - C o n s t r u c t e d} \\ \mathbf{2}-\text { Stable } & \mathbf{3} \text { - Aggraded } \\ \mathbf{4} \text { - Degraded } & \mathbf{5} \text { - Laterally unstable } \\ \mathbf{6} \text { - Vertically and laterally unstable }\end{array}$


108. Evolution comments (Channel evolution not considering bridge effects; See HEC-20, Figure 1 for geomorphic descriptors):

protection starts at end of dry masonry end of RB DSWW to beyond 30 feet DS.

The protection on the left and right bank downstream consists of dumped quarried stone. 


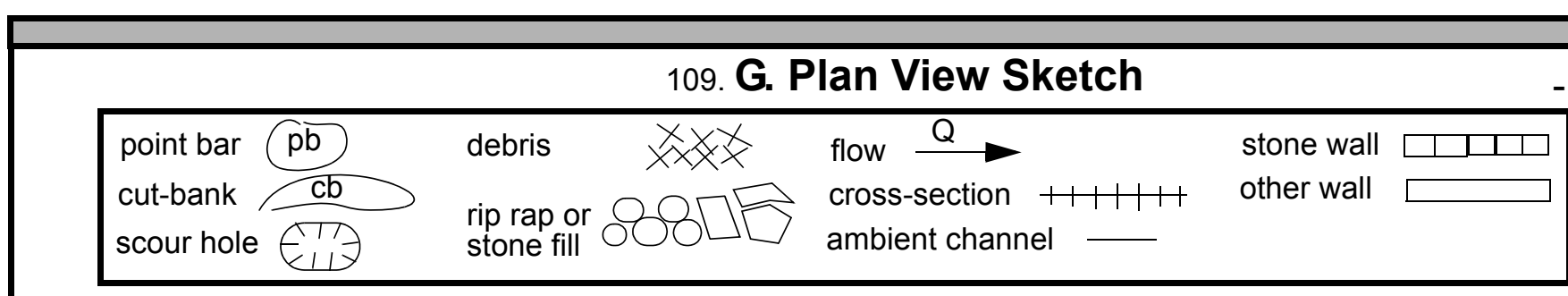


APPENDIX F:

SCOUR COMPUTATIONS 
SCOUR COMPUTATIONS

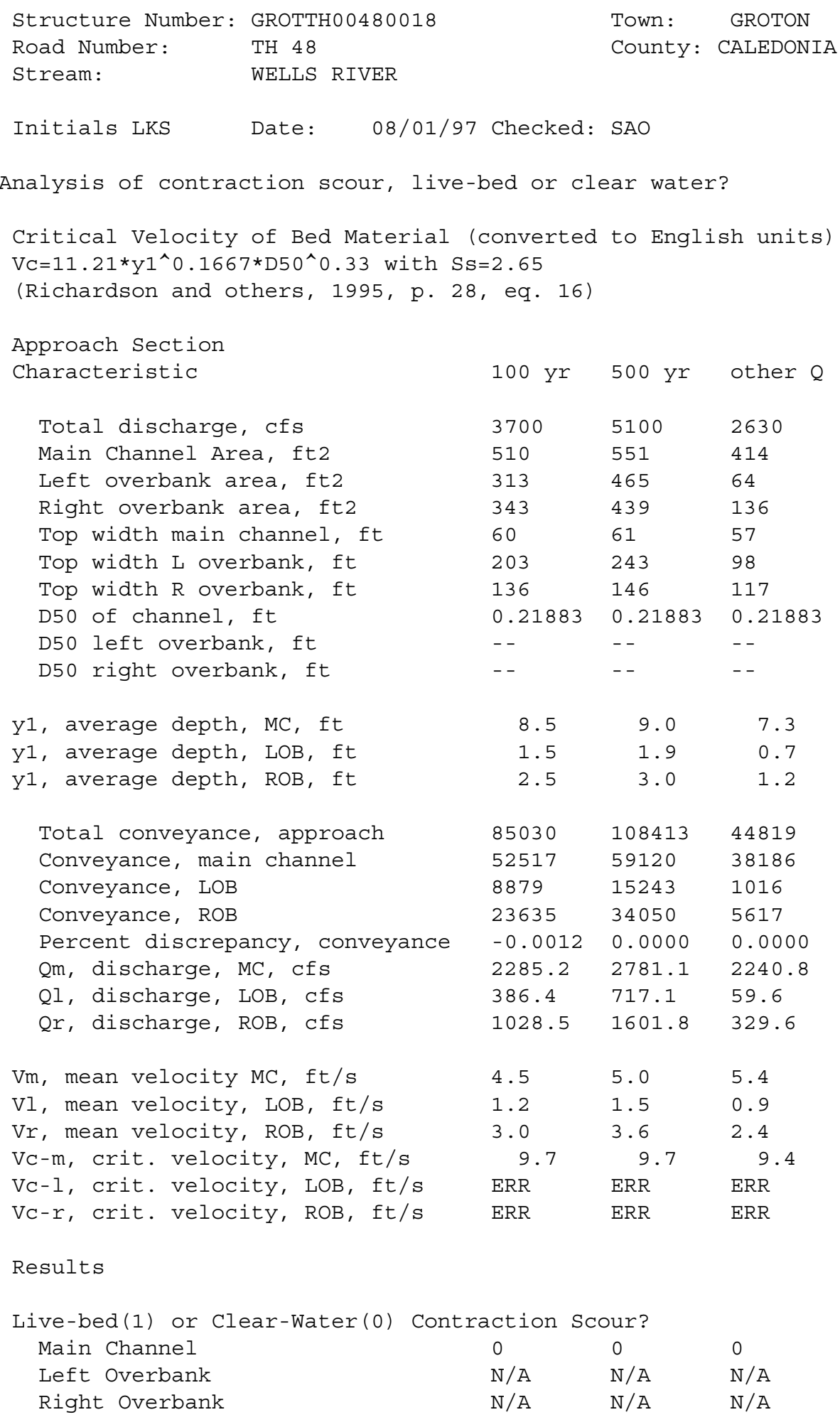


Clear water Contraction Scour in MAIN CHANNEL

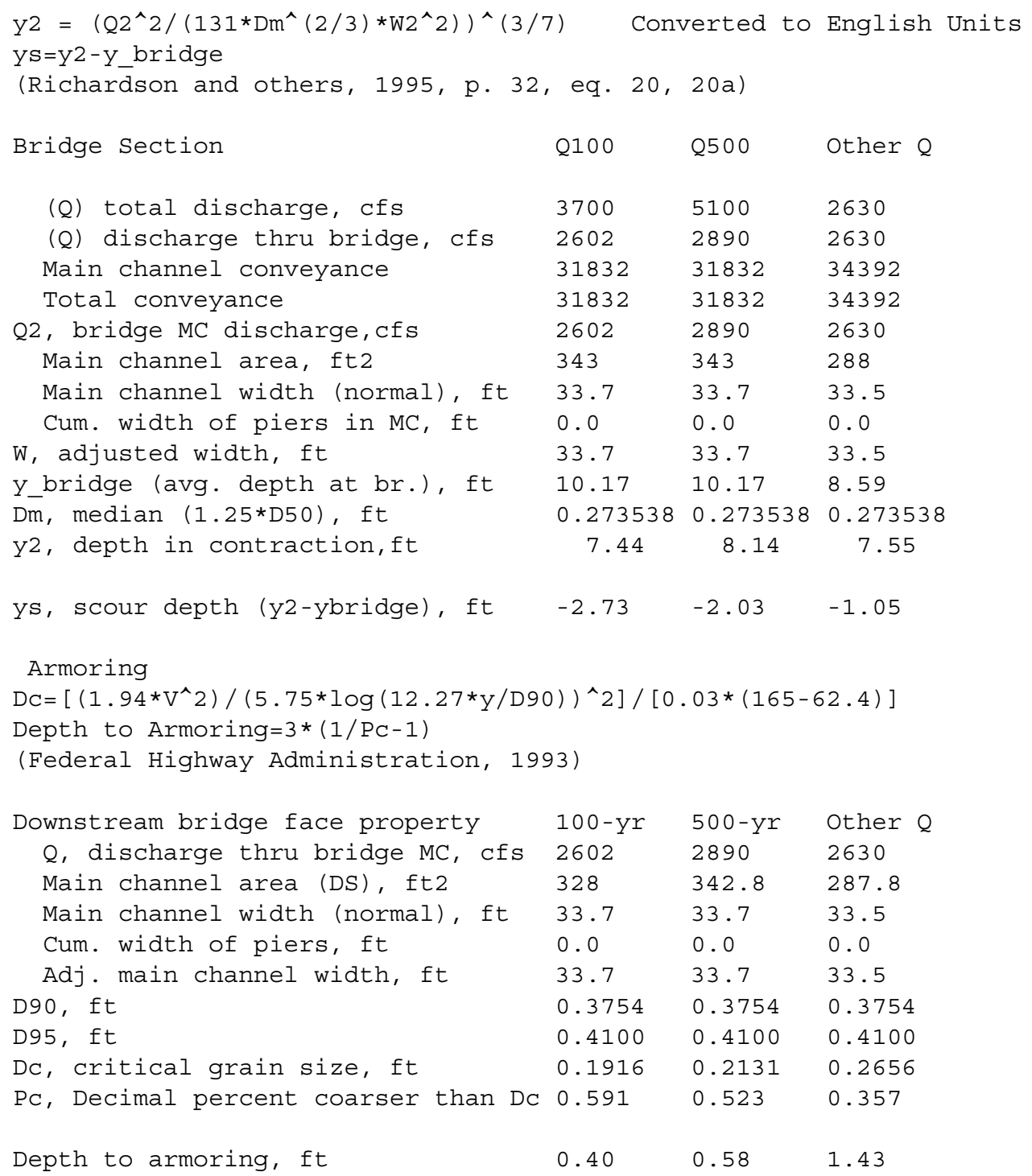




\begin{tabular}{|c|c|c|c|}
\hline \multicolumn{4}{|c|}{$\begin{array}{l}\text { Umbrell pressure flow equation } \\
(\mathrm{Hb}+\mathrm{Ys}) / \mathrm{ya}=1.1021 *[(1-\mathrm{w} / \mathrm{ya}) *(\mathrm{Va} / \mathrm{VC})] \wedge 0.6031 \\
(\text { Richardson and other, 1995, p. 144-146) }\end{array}$} \\
\hline & Q100 & Q500 & OtherQ \\
\hline Q, total, cfs & 3700 & 5100 & 2630 \\
\hline Q, thru bridge $M C$, cfs & 2602 & 2890 & 2630 \\
\hline Vc, critical velocity, ft/s & 9.65 & 9.75 & 9.40 \\
\hline Va, velocity MC approach, ft/s & 4.48 & 5.05 & 5.41 \\
\hline Main channel width (normal), ft & 33.7 & 33.7 & 33.5 \\
\hline Cum. width of piers in MC, ft & 0.0 & 0.0 & 0.0 \\
\hline W, adjusted width, ft & 33.7 & 33.7 & 33.5 \\
\hline qbr, unit discharge, ft2/s & 77.2 & 85.8 & 78.5 \\
\hline Area of full opening, ft2 & 342.8 & 342.8 & 287.8 \\
\hline Hb, depth of full opening, ft & 10.17 & 10.17 & 8.59 \\
\hline Fr, Froude number, bridge $\mathrm{MC}$ & 0.42 & 0.47 & 0 \\
\hline Cf, Fr correction factor $(<=1.0)$ & 1.00 & 1.00 & 0.00 \\
\hline **Area at downstream face, ft2 & 328 & $\mathrm{~N} / \mathrm{A}$ & $\mathrm{N} / \mathrm{A}$ \\
\hline **Hb, depth at downstream face, ft & 9.73 & $\mathrm{~N} / \mathrm{A}$ & $\mathrm{N} / \mathrm{A}$ \\
\hline **Fr, Froude number at DS face & 0.45 & ERR & ERR \\
\hline **Cf, for downstream face $(<=1.0)$ & 1.00 & $\mathrm{~N} / \mathrm{A}$ & $\mathrm{N} / \mathrm{A}$ \\
\hline Elevation of Low Steel, ft & 497.39 & 497.39 & 0 \\
\hline Elevation of Bed, ft & 487.22 & 487.22 & -8.59 \\
\hline Elevation of Approach, ft & 498.57 & 499.25 & 0 \\
\hline Friction loss, approach, ft & 0.12 & 0.16 & 0 \\
\hline Elevation of WS immediately US, ft & 498.45 & 499.09 & 0.00 \\
\hline ya, depth immediately US, ft & 11.23 & 11.87 & 8.59 \\
\hline Mean elevation of deck, ft & 500.43 & 500.43 & 0 \\
\hline w, depth of overflow, ft $(>=0)$ & 0.00 & 0.00 & 0.00 \\
\hline Cc, vert contrac correction $(<=1.0)$ & 0.98 & 0.96 & 1.00 \\
\hline$* * \mathrm{Cc}$, for downstream face $(<=1.0)$ & 0.965079 & ERR & $\mathrm{ERR}$ \\
\hline Ys, scour w/Chang equation, ft & -1.97 & -1.03 & $\mathrm{~N} / \mathrm{A}$ \\
\hline Ys, scour w/Umbrell equation, ft & -2.38 & -1.38 & $\mathrm{~N} / \mathrm{A}$ \\
\hline
\end{tabular}


**Ys, scour w/Umbrell equation, ft -1.94 N/A ERR

In UNsubmerged orifice flow, an adjusted scour depth using the Laursen equation results and the estimated downstream bridge face properties can also be computed (ys=y2-ybridgeDs)

Y2, from Laursen's equation, ft $7.44 \quad 8.14 \quad 7.55$

WSEL at downstream face, ft $496.96 \quad--$

Depth at downstream face, ft $9.73 \quad \mathrm{~N} / \mathrm{A} \quad \mathrm{N} / \mathrm{A}$

Ys, depth of scour (Laursen), ft -2.29 N/A N/A

Abutment scour

Froehlich's Abutment Scour

$\mathrm{Ys} / \mathrm{Y} 1=2.27 * \mathrm{~K} 1 * \mathrm{~K} 2 *\left(\mathrm{a}^{\prime} / \mathrm{Y} 1\right)^{\wedge} 0.43 * \mathrm{Fr} 1^{\wedge} 0.61+1$

(Richardson and others, 1995, p. 48, eq. 28)

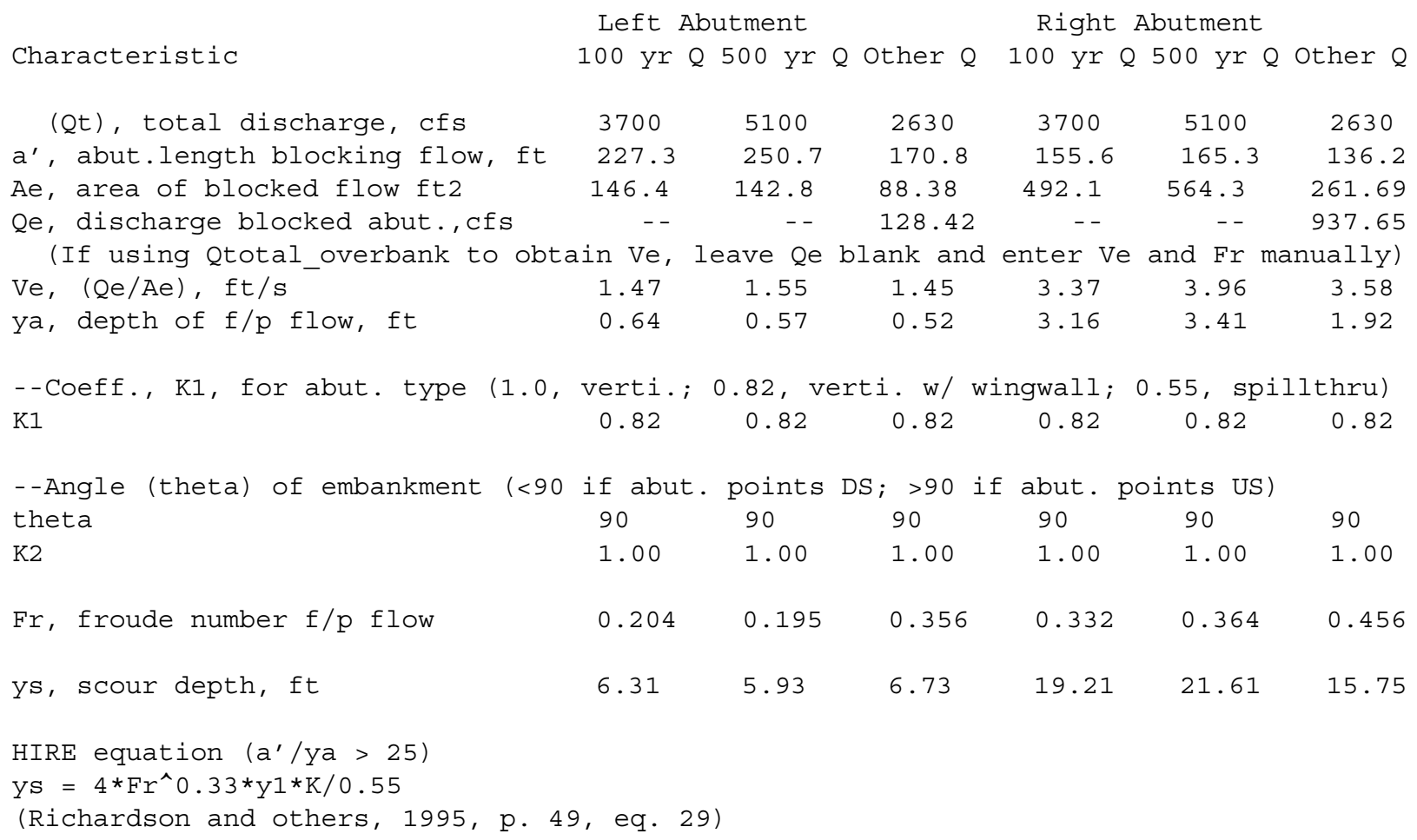




\begin{tabular}{|c|c|c|c|c|c|c|}
\hline$a^{\prime}$ (abut length blocked, ft) & 227.3 & 250.7 & 170.8 & 155.6 & 165.3 & 136.2 \\
\hline y1 (depth $f / p$ flow, ft) & 0.64 & 0.57 & 0.52 & 3.16 & 3.41 & 1.92 \\
\hline$a^{\prime} / y 1$ & 352.90 & 440.13 & 330.08 & 49.20 & 48.42 & 70.89 \\
\hline Skew correction (p. 49, fig. 16) & 1.00 & 1.00 & 1.00 & 1.00 & 1.00 & 1.00 \\
\hline Froude no. f/p flow & 0.20 & 0.20 & 0.36 & 0.33 & 0.36 & 0.46 \\
\hline Ys w/ corr. factor K1/0.55: & 2.77 & 2.42 & 2.68 & 15.99 & 17.79 & 10.78 \\
\hline vertical w/ $\mathrm{ww}^{\prime} \mathrm{s}$ & 2.27 & $\begin{array}{l}2.42 \\
1.98\end{array}$ & $\begin{array}{l}2.08 \\
2.19\end{array}$ & $\begin{array}{l}15.99 \\
13.11\end{array}$ & 14.59 & 8.84 \\
\hline spill-through & 1.52 & 1.33 & 1.47 & 8.79 & 9.78 & 5.93 \\
\hline Abutment riprap Sizing & & & & & & \\
\hline Isbash Relationship & & & & & & \\
\hline $\begin{array}{l}\mathrm{D} 50=\mathrm{Y}^{*} \mathrm{~K} * \mathrm{Fr} \mathrm{r}^{\wedge} /(\mathrm{Ss}-1) \text { and } \mathrm{D} 50=\mathrm{Y} * \mathrm{~K} * \\
\text { (Richardson and others, 1995, p11 }\end{array}$ & $\begin{array}{l}2)^{\wedge} 0.1 \\
\text { eq. } 81\end{array}$ & $(S s-1)$ & & & & \\
\hline Characteristic & Q100 & Q500 & Other Q & Q100 & Q500 & Other $Q$ \\
\hline Fr, Froude Number & 0.45 & 0.47 & 0.55 & 0.45 & 0.47 & 0.55 \\
\hline$y$, depth of flow in bridge, ft & 9.73 & 10.17 & 8.59 & 9.73 & 10.17 & 8.59 \\
\hline Median stone Diameter for riprap & $\therefore$ left & outment & & right & abutment, & ft \\
\hline Fr $<=0.8$ (vertical abut.) & 1.22 & 1.39 & 1.61 & 1.22 & 1.39 & 1.61 \\
\hline Fr>0.8 (vertical abut.) & ERR & ERR & ERR & ERR & ERR & ERR \\
\hline Fr $<=0.8 \quad$ (spillthrough abut.) & 1.06 & 1.21 & 1.40 & 1.06 & 1.21 & 1.40 \\
\hline Fr>0.8 (spillthrough abut.) & ERR & ERR & ERR & ERR & ERR & ERR \\
\hline
\end{tabular}

